\title{
Mechanisms for inclusion and exclusion through digital political participation: Evidence from a comparative study of online consultations in three German cities
}

\author{
Bastian Rottinghaus · Tobias Escher
}

Published online: 3 August 2020

(C) The Author(s) 2020

\begin{abstract}
Consistent findings of unequal political participation have been motivating different democratic innovations, including those that utilize the opportunities of information and communication technologies for political online participation. While previous research has established only a limited mobilizing potential of digital media, we still lack a good understanding of the mechanisms leading citizens to decide for or against engagement online. Therefore, we investigate who participates in opportunities for political online participation, what explains (non)-engagement and how effective personalized invitations are to increase and diversify participation. To address these questions, we conducted a comparative study of three almost identical instances of local online participation, relying on evidence from surveys of registered users and random samples of the local population.

Our results show that engagement in online participation is indeed significantly biased from the population towards resource-rich individuals who also differ in their assessment of the participation process and its results. This is despite the fact that knowledge of these participation opportunities is equally distributed among all social groups. While online aversion is a barrier for some, distrust in the participation process and lack of interest are more powerful reasons to refrain from engagement. Using a randomized-controlled field experiment we can confirm that personalized invitations are an effective instrument for mobilization that increased participation by a factor of four to seven and that can to a limited degree elicit participation from under-represented groups. These findings have a number of important implications for researchers and practitioners who aim to increase equality in political participation.
\end{abstract}

Dr. B. Rottinghaus · Jun.-Prof. Dr. T. Escher $(\bowtie)$

Institute for Social Sciences / Düsseldorf Institute for Internet and Democracy, Heinrich Heine University Düsseldorf, Universitätsstraße 1, 40225 Düsseldorf, Germany

E-Mail: tobias.escher@hhu.de 


\section{Introduction}

Political participation as the voluntary activity of citizens with the aim of influencing political decisions is an essential element of democratic systems. The basic premise of democracy as the rule of the people requires as a minimum the participation of citizens in regular elections to choose the political personnel. Most normative theories of democracy place a high value on regular citizen participation beyond elections as they expect it to ensure responsiveness between citizens and representatives (Dahl 1989; Pitkin 1967), improve decision-making by incorporating additional knowledge and rational discourse (Habermas 1992), transform opinions and achieve consensus and educate citizens in civic values and skills (Barber 1984; Pateman 1970).

This crucial role of participation places demands on the nature of participation. If participation is a necessary condition of democracy, then it becomes important who participates and with what interests. Substantive political equality requires not only equality of opportunity to participate for every member of the polis, but also equality of actual ability to participate, in other words sufficient resources such as education, time and money, and equal responsiveness of representatives (Dahl 1989; Verba 2003).

In this paper we focus on political participation via online means, the reasons for the commonly low and biased engagement in this form of participation and possible strategies to address these issues. A key concern of empirical research into the structure of political participation has usually focused on how many people participate and to what degree these are representative in terms of major social characteristics such as gender, age and education. This derives from the assumption that many interests are associated with sociodemographic characteristics. Research has indeed established that policies tend to reflect the interests primarily of those (affluent) parts of society that usually engage in political matters (Bartels 2008; Elsässer et al. 2017; Gilens 2005). As “unequal participation spells unequal influence” (Lijphart 1997, p. 1), social inequality translates into political inequality.

The exceptionally well-researched structure of political participation has clearly established the substantial political inequalities associated with participation. In particular it is those parts of the population with higher socioeconomic status (as expressed by occupation, income and education) who participate most often, and of those in particular, people in their middle-ages (40-60) and men (Dalton 2017; Gabriel and Völkl 2008; Stark 2019; Steinbrecher 2009; Verba et al. 1995). While this holds for political participation in general, marked differences can be observed between different forms of participation. It is in particular the "unconventional" forms of participation such as signing petitions or boycotting products that have gained more prominence but at the same time exhibit the greatest socioeconomic inequalities (Schäfer 2012).

What is more, there have been long-standing concerns about a legitimacy gap among democratic publics (Dalton 2004). While research has shown that citizens' political support for their political community as well as the regime principles of democracy have not been falling but instead rising, there is indeed more negative evidence on citizens' satisfaction with the actual performance of democracy in their country and the political institutions and actors responsible (Kneip et al. 2020; Norris 
2011; van Ham et al. 2017). Regardless of the actual extent of a legitimacy gap, this discourse and the consistent findings of unequal political participation have both been motivating different democratic innovations, many of which are specifically targeted at increasing citizen engagement in decision-making processes (Smith 2009). These include amongst others mini-publics, participatory budgeting or citizen referenda but also innovations that utilize the opportunities of information and communication technologies, for example for online consultations and collaborations. These have sparked hopes and fears alike for more and more equal participation.

In this article, we will review the arguments for a mobilizing potential of what is referred to here as online participation. As our summary of the empirical findings of previous research shows, there is only a limited mobilizing effect of digital media overall. However, we will argue that previous research has left important questions unanswered about the mechanisms that lead individuals to engage online or to refrain from it. Therefore, we investigate four research questions:

(i) Who participates in opportunities for political online participation,

(ii) why do people (not) participate online,

(iii) how effective are personalized invitations to increase and diversify participation as one particular mobilization strategy and

(iv) how do those mobilized differ in their attitudes and activities from those who become engaged without particular stimuli.

To address these questions, we conducted a comparative study of three almost identical instances of local online participation that allow tracing in detail the characteristics and the attitudes of both participants and non-participants. After a brief overview of the design of this research project, we discuss the results, showing that participants in online participation are indeed significantly biased from the population towards resource-rich individuals, and also differ in their assessment of the process and its results. In addition, by making use of a randomized-controlled field experiment we can show that only about a quarter of citizens know about the individual process in question, and that while online aversion is a barrier for some, distrust in the participation process and lack of interest are more powerful reasons to refrain from engagement. What is more, we can confirm that personalized invitations are an effective instrument for mobilization that increases participation rates by a factor of four to seven, and that can mobilize at least some participants from under-represented groups, but only for rather low-intensity engagement. These findings have a number of important implications for researchers and practitioners alike that we discuss in the final part of this paper.

\section{The Internet and political participation}

Among the empirical democratic theories aiming to explain political participation, the civic voluntarism model by Verba et al. (1995) has gained particular prominence. It explains individuals' decision to participate or not with the available resources (in terms of time, money or education), their motivation (in terms of their general political interest or specific concerns) and their networks in which they are organized 
and that act as mobilizing factor. Therefore, the participation patterns reflect both ability to participate through knowledge and networks, and also cognitive mobilization such as political interest and political efficacy that compel someone who is able to engage to actually participate. Crucially, these latter cognitive factors are strongly connected to social status (in particular education) and so are again highly unequal and stable across generations (Stark 2019; Steinbrecher 2009; Verba et al. 1995).

Based on the normative perspective that more and in particular more equal participation is desirable, the growing opportunities provided by digital communication technologies have been critically examined for their potential to address the problem that unequal participation represents. Using the civic voluntarism model as a starting point, all three sources of participation (i.e. resources, motivation and networks) are affected by the affordances of digital communication technologies in ways that could either lead to greater and more equal participation as the mobilization hypothesis assumed, or could reinforce and deepen existing participation patterns as the normalization thesis suspects (Gibson et al. 2005).

Turning first to resources, by lowering participation costs and enabling engagement independent of time and space, online participation could enable more people to engage. At the same time, using these opportunities requires not only resources (such as Internet access) but also certain informational skills. In terms of motivation, it has been hypothesized that additional information such as increased transparency, immediate feedback for participatory acts or regular push notifications could increase the motivation for participation. What is more, the amount of political information available might increase political interest (Boulianne 2011). At the same time, the sheer breadth of alternative offers can easily distract people and lead them to nonpolitical activities (Prior 2005). Finally, it is obvious that the Internet offers new ways for groups of like-minded people to come together to exchange ideas and organize collective action (Lupia and Sin 2003). At the same time, these networks might only result in low-level activity, sometimes called clicktivism or slacktivism (Karpf 2010).

More than two decades of research into the mobilization potential of the Internet have shown that despite considerable variation, if anything, online participation has had only a small effect on the share of people engaging in politics. A milestone study in reviewing existing research has been the work of Boulianne (2009) who reviewed 38 studies of the Internet and engagement in the US, finding no decline but indications for a slight positive effect of Internet use on engagement. The mobilization effect on numbers is small and often inconsistent. A rare longitudinal study in Germany found no consistent effect on participation rates (Emmer et al. 2011) while another study assumes a small increase (Kroh and Neiss 2012). In sum, there seems to be an effect of Internet use, even though small, on the number of people engaging in politics (Anduiza et al. 2012).

When few are mobilized to participate, it comes as no surprise that the effect on existing, highly biased participation structures remains small. Indeed, while in some instances under-privileged groups could benefit from electronic forms of participation (Marschall and Schultze 2012; Wampler and Sampaio 2011), by and large empirical research has shown little evidence for the mobilization of traditionally under-represented groups. Instead, with the exception of young people, those using 
online means of engagement tend to be not more but rather less representative of the population than those who use traditional means of participation (Escher 2013; Oser et al. 2012; Schlozman et al. 2010).

It has become clear that the resources to engage in political participation are not equally distributed. While access has become less of a problem, the willingness as well as the skills to utilize the Internet for political purposes exist primarily among the resource-rich parts of the population (Helsper and Reisdorf 2017; Marr and Zillien 2010; Norris 2001). Furthermore, it needs to be acknowledged that a simple opportunity to engage online still requires a motivation to do so in the first place (Jorba and Bimber 2012, p. 22). While studies have established that Internet use can indeed stimulate political interest even among traditionally less active groups of the population, these effects are stronger for those already politically engaged (Boulianne 2011; Colombo et al. 2012; Schöttle 2019), resulting in a virtuous circle mobilising those already engaged (Norris 2000).

In reviewing the state of research, it is obvious that digital technologies have hardly lived up to the more optimistic expectations regarding a widespread mobilization of previously passive parts of the population. If anything, the new technological opportunities have afforded only slight increases in activation that have-with the possible exception of younger people-been mainly limited to the traditionally overrepresented strata of the population already active. However, we still lack a good understanding of the mechanisms leading citizens to decide for or against engagement in online participation, and consequently, which strategies can be applied to effectively mitigate issues of unequal participation (Kubicek and Aichholzer 2016).

Therefore, this study aims to investigate four research questions: The first question explores the structure of online participation and asks (i) who participates in opportunities for political online participation. While we can expect to find the unequal patterns that have been documented extensively, information about participants and non-participants is the basis for the second research question that investigates the factors explaining the decision to participate and asks (ii) why do people (not) participate online. We argue that many of the previous studies were not well equipped to address this question. First of all, many of the studies cited so far would analyze online participation as a uniform and homogenous form of participation. We argue that in order to trace mechanisms it is necessary to focus on specific instances of participation. This is first of all because we know from ample previous research that the structure of engagement varies depending on the actual mode of engagement (Stark 2019; Steinbrecher 2009). For example, based on a sample of German citizens, Theocharis and van Deth (2018, p. 100) have shown that men are more likely to engage in digitally networked participation (which denotes e.g. commenting on social media sites) while women are more likely to engage in consumerist acts such as product boycotts.

Second, while numerous studies do exist that have focused on particular instances of online participation, with rare exceptions (for Germany see Faas et al. 2016; Schneider 2018) these have usually only examined those who do take part with little evidence from those who do not, partly because it poses a greater challenge to reach out to those who remain invisible in participation processes (see for example Aichholzer et al. 2016; Escher and Riehm 2017; Kim and Lee 2012; Kubicek et al. 
2011; Marschall and Schultze 2012; Maxhofer 2019). Consequently, we tend to know little about the reasons of those who remain inactive. What is more, such analysis has been mainly limited to the sociodemographic characteristics of those who do (not) take part, yet to understand the full implications of the repeatedly observed biases, it is important to assess how participants and non-participants differ in their attitudes towards the respective processes and politics more generally.

Finally, the problems in engaging citizens in participation processes documented by research so far give rise to the question of which means do actually work, and hence for investigating promising avenues in order to motivate citizens to have a say. Previous experiences suggest that personalization is an effective strategy in getting people to participate, e.g. in surveys (Dillman et al. 2007; Sinclair et al. 2012). However, existing research did not test this mobilizing effect in a controlled setting. Therefore, in addition to the two main research questions outlined above, we also investigate (iii) how effective personalized invitations are to increase and diversify participation, i.e. whether not only more people participate but also people from commonly under-represented backgrounds. In addition, so far little is known about whether these people differ in their characteristics or their attitudes from those who participate without invitation so we also ask (iv) how do those mobilized differ in their attitudes and activities from those who become engaged without particular stimuli.

This research aims to address these questions with a design that is discussed in the following section.

\section{Research design \& methodology}

\subsection{Participation on the local level}

In order to investigate who participates online and the factors that contribute to the individual decision for or against participation, we decided to focus on instances of online participation on the local level. Here citizens are directly affected by political decisions, and consequently studies have shown a high public demand for participation (Gabriel and Kersting 2014, p. 82). Also, local governments have long been a testing ground for government reforms and new democratic innovations, including online participation (Åström and Grönlund 2011; Gabriel and Kersting 2014). Data from the German state North Rhine-Westphalia shows that about a third of municipalities have used forms of online participation already (Steinbach et al. 2020). In addition, a focus on the local level reflects the methodological considerations highlighted in the previous section as it affords not only to observe specific instances of participation closely, but it also clearly delineates the target population of the participation process and allows the random sampling (via the local registration offices) necessary for a representative population survey.

Evidence on the structure of local political participation in general is somewhat rarer but basically shows the same patterns of low and biased participation (Gabriel 2013; Gabriel and Kersting 2014; Michels and de Graaf 2010; van Deth and Tausendpfund 2013; Vetter 2008). In contrast, research on online participation 
has focused more often on the local level than on higher levels of government (Freschi et al. 2009; Susha and Grönlund 2012). However, for Germany, academic studies of local participation online are rare (Kubicek and Westholm 2010; Schneider 2018) as most of the available evidence derives from evaluation reports. While these show that participants in online forms of engagement are even more biased towards men and high-status individuals, these do not investigate in detail users let alone nonparticipants (see for example Diefenbach 2013; Märker and Ruesch 2012; Taubert et al. 2010).

\subsection{The cases}

In order to investigate in detail how citizens engage in online participation processes, we chose to conduct three almost identical instances of online consultations that we designed and implemented together with three different German municipalities (Bonn, Cologne \& Moers). Within these online consultations the respective local governments invited their citizens to suggest locations on an online map where the situation for cyclists should be improved, e.g. by introducing new cycle lanes, by creating more opportunities for parking bicycles or by enforcing car parking violations endangering cyclists. Apart from making proposals, participants could also comment on the proposals of others as well as rate them-only for the latter function was it necessary to register on the site that could otherwise be used anonymously.

All three consultations were conducted for five weeks in autumn 2017. They employed the same map-based technological platform with largely identical information materials. Over the course of five weeks, citizens in all three cities together made about 3200 suggestions along with 2200 comments. The results of these consultation processes were to be discussed in relevant political committees (usually planning) and would feed into the various ongoing infrastructure programs. By early 2020 these citizen contributions had resulted in a number of low-level changes in infrastructure, while many were still being discussed by the respective political planning committees in order to determine specific measures to be implemented over the next years.

Public consultations are instruments that public authorities utilize to gather citizens' input into the decision-making process. By definition citizen consultations remain consultative, i.e. without transferring any formal decision-making power to citizens (Fung 2006). However, they serve an important function in ensuring responsiveness between citizens and representatives and are regularly used by local councils in both formal (such as land use planning) and informal processes such as in our cases. While the repertoire of political participation is constantly expanding, we have purposefully chosen to focus on a participatory activity that is clearly within the focus of most if not all definitions of political participation, as it takes place within the established political institutions and with the explicit purpose to influence political decisions. As Theocharis and van Deth (2018) argue convincingly, activities that take place outside of political institutions (including community activity and political expressions on social media) are important in mobilizing people and influencing politics as well. However, from a normative perspective we argue that equality of participation is particularly important when authorities invite citizens' 
contributions to inform future decision. In addition, from an individual perspective we might expect motivation to participate to be higher when the authority is signaling interest in contributions as in the case in such forms of top-down initiated participation.

Clearly, the issue at stake within a participatory process has important implications for how many and which citizens participate. The choice of cycling as the topic of the online consultation had the benefit that it is of a comparatively high relevance not just for cyclists but for all people living in the city as well as those using its infrastructure (such as commuters or shoppers). What is more, the issue involved mainly concrete measures to be implemented in infrastructure, like bike parking or cycle lanes, and as such were tangible and of a timeframe that could be envisaged. We believe that this would help to motivate participation.

Participation is shaped not only by individual factors but also by the context in which it takes place, for example through differing institutions and regulations (Gabriel 2013). The consultations were conducted in Bonn, Moers and the district Ehrenfeld within the city of Cologne (see Table 7 for details), all located in the same German state (North Rhine-Westphalia) to keep the wider legal and cultural context stable. The two cities and the district represent different sizes (ranging from 100,000 up to about 300,000 inhabitants) as well as different levels of experience with previous online consultations by the municipality. Beyond this the choice of the three cities reflect basically a convenience sample as we relied on the cooperation of the municipality to conduct an online consultation with the research team. The topic of cycling has a permanent relevance (in contrast to topical issues) which allowed us to conduct the consultations in all three cities at the same point in time. This reduced potential confounding influences through other external events such as changes in federal government support for sustainable mobility. However, how the consultations are embedded within the city-specific discourse and measure on mobility differs between the municipalities. Our interest here is primarily to establish general patterns of participation and motivation. While we control for city-specific difference in the later analysis, this is not intended as a test of context-specific properties but to check if the city context is a genuine influence amongst the other factors.

\subsection{Data collection}

In order to assess the characteristics and attitudes of both participants as well as nonparticipants we conducted two types of survey. The first type was an online survey of those people actively engaging in the online consultation processes. To this end we invited all users who had registered on the platforms. The response rates to the online surveys among registered participants of the consultation processes was rather satisfactory: $45 \%(N=268)$ of the registered participants of the consultation process in Bonn responded to the survey invitation via e-mail, and in Ehrenfeld $(N=65)$ and Moers $(N=61)$ it was even $47 \%$.

The second type of survey aimed to collect information on the attitudes of those not participating. To this end, a mail survey was administered to a random sample of the respective local population (all resident citizens 18 years and older). We included 
citizens without German citizenship (i.e. often with lower German language skills) which should have decreased response rates somewhat. The response rates were $27 \%(N=625)$ in Ehrenfeld and 29\% $(N=690)$ in Moers. In Bonn we conducted a panel survey. In the pre-process survey 34\% $(N=1640)$ of the 5000 randomly chosen citizens replied. We attribute this higher response rate both to the timing (some weeks before the general election) as well as the peculiar structure of the population of Bonn (the rate of citizens with Abitur is about a third higher than the German average). Of those surveyed before the consultation, only 67\% agreed to be contacted again for scientific purposes $(N=1094)$, and of these respondents only $71 \%(N=778)$ responded a second time in the post-process survey. In total the aggregated dataset from these six sources consists of $N=2487$ cases. The surveyed samples exhibit some typical biases common to voluntary surveys and which can be described as a "middle class-bias" (Diekmann 2004, p. 361p). Table 8 in the Appendix reports more information on survey sample composition in relation to population statistics. These biases have to be kept in mind when we compare the attributes of those who participated in the consultations to those who did not.

We were also interested in the ways in which citizens could be mobilized to engage in the online consultation. We decided to test a very simple mobilization strategy in which personalized invitations were sent by the city council to a random sample of the population by mail in the form of a letter or a postcard informing them about the process and inviting them to participate. For this randomized-controlled field experiment we selected random sub-samples from the address data we used to contact our survey respondents. In Bonn 4000 of 5000 (80\%) received a letter inviting them to the consultation process, while in Ehrenfeld and Moers the figure was 1667 of $2500(66 \%)$.

\subsection{Operationalization and analysis}

In order to investigate who participates in local online participation and which factors contribute to this engagement, we focus mainly on a comparison between those people who did participate in the online consultation process and those who did not. We divide the cumulated dataset into four subsets that are summarized in Table 1. Sample $S_{1 a}, S_{1 b}$, and $S_{1 c}$ are selected from sample $S_{1}$, the cumulated dataset of the three representative post-process mailing-surveys based on random samples from the local population in Bonn, Ehrenfeld, and Moers. While $S_{1 a}$ includes those respondents who did not participate in the consultation process, $S_{1 b}$ covers those who did participate: actively - by contributing proposals, comments, and/or ratings to the consultation process - or passively by only visiting the online platform to get an idea of the ongoing discussion. We use this rather wide definition of participation because visiting the online consultation represents already a certain degree of activity. At a later point of our analysis we will differentiate between active and passive participants to provide further insights regarding differences between active and passive participation. As a particular subset of $S_{1 \mathrm{a}}$, the sample $S_{1 \mathrm{c}}$ includes those who did not participate but who had heard of the consultation and apparently actively chose to abstain. $S_{2}$ on the other hand includes all cases from the three online surveys among the registered participants of the consultation. Please note 
Table 1 Description of subsamples

\begin{tabular}{|c|c|c|}
\hline Sample & Description & $\begin{array}{l}\text { Respon- } \\
\text { dents } \\
(N)\end{array}$ \\
\hline $\mathrm{S}_{1}$ & $\begin{array}{l}\text { Cumulated Dataset of representative surveys } \\
\text { in Bonn }(N=768), \text { Ehrenfeld }(N=598) \text { and } \\
\text { Moers }(N=653)\end{array}$ & 2019 \\
\hline $\mathrm{S}_{1 \mathrm{a}}$ & $\begin{array}{l}\text { Sub-sample of } S_{1} \text { : Respondents who did not } \\
\text { participate in the consultation }\end{array}$ & 1819 \\
\hline $\mathrm{S}_{1 \mathrm{~b}}$ & $\begin{array}{l}\text { Sub-sample of } \mathrm{S}_{1} \text { : Respondents who did par- } \\
\text { ticipate in the consultation }\end{array}$ & 200 \\
\hline $\mathrm{S}_{1 \mathrm{c}}$ & $\begin{array}{l}\text { Sub-sample of } \mathrm{S}_{1 \mathrm{a}} \text { : Respondents who did not } \\
\text { participate in the consultation, but heard of it }\end{array}$ & 567 \\
\hline $\mathrm{S}_{2}$ & $\begin{array}{l}\text { Cumulated Dataset of respondents from online } \\
\text { surveys of registered participants in Bonn } \\
(N=268) \text {, Ehrenfeld }(N=65) \text {, and Moers } \\
(N=61)\end{array}$ & 394 \\
\hline
\end{tabular}

that the stated significance levels concerning the comparison of $S_{1}$ and $S_{2}$ must not be interpreted in the strict sense of inferential statistics, since they stem from different samples and one of them, $\mathrm{S}_{2}$, is not even a random sample. Nevertheless, we decided to include this information to reflect the ratio of effect sizes to sample sizes.

In order to assess what are potential factors explaining (non-)participation beyond the treatment, we investigate a number of standard predictors of political participation derived from the civic voluntarism model (Verba et al. 1995). These include the basic sociodemographics of age and gender, as well as education and income, as indicators for the resources available for participation. In addition, a number of measures are aimed at tapping into the personal orientations of individuals because these are decisive factors that lead those with an ability to participate (through sufficient resources) to actual participation. Specifically, we include internal political efficacy as the subjective assessment of one's political competencies and ability to talk about political issues (Beierlein et al. 2012). We also include a political action scale that measures the amount of previous political engagement in non-institutionalized political participation. This is a measure of accumulated civic skills in the area of political participation and expresses how much one is capable of and interested in participation. As participation might be motivated by dissatisfaction with politics, we also include a measure of how satisfied respondents are with the performance of local institutions. For this we used an approach of Ferrín and Kriesi (2016) for the European Social Survey that lets citizens compare how much the actual performance of political institutions matches their principles, and rephrased this for local politics. This allows us to assess to what degree citizens are (dis)satisfied with the way they are involved in local decision-making. While these measures are related to the propensity to engage in participation in general, we also add indicators to measure topic-specific motivation. As we would expect that regular bicycle users and people who are dissatisfied with the infrastructure are particularly affected by the topic of the consultation, we include the daily biking distance and the satisfaction with bicycle infrastructure. Please refer to Table 2 for a detailed operationalization 


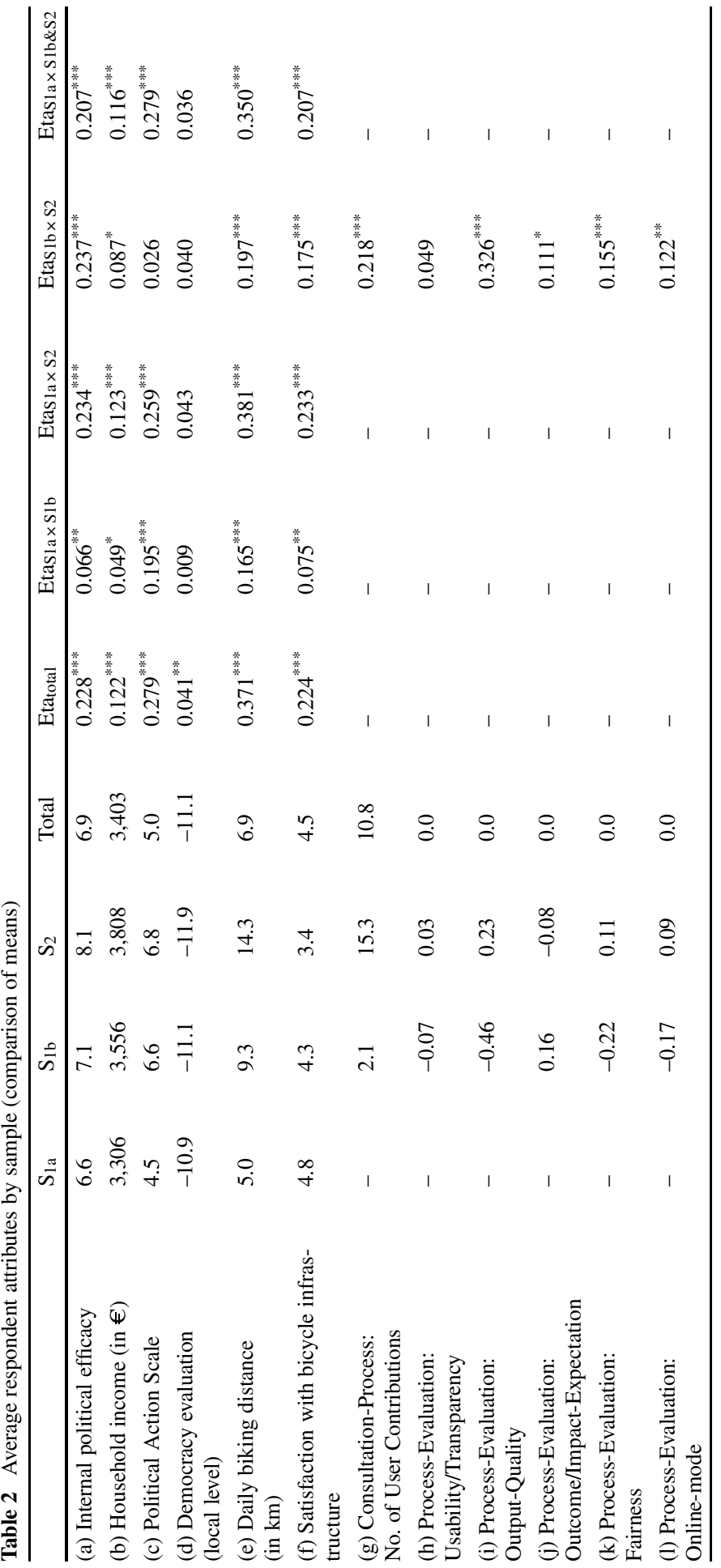




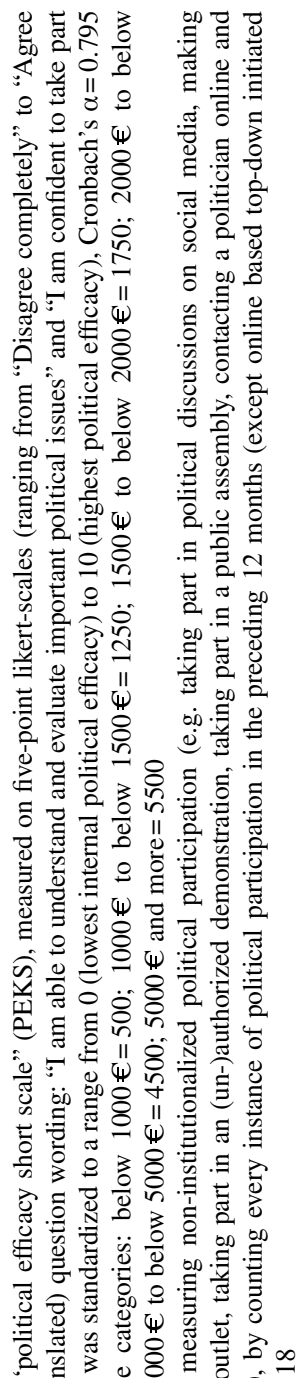

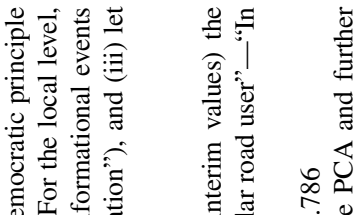

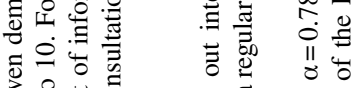

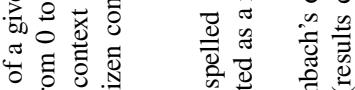

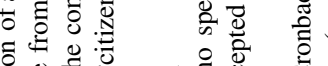

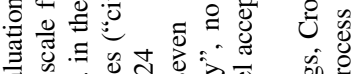

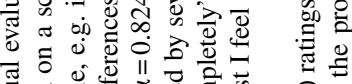

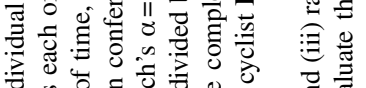

늘

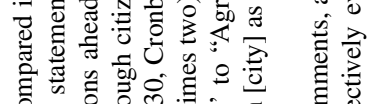

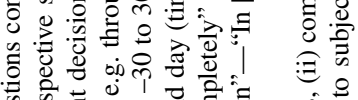

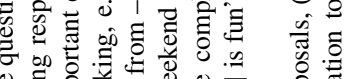

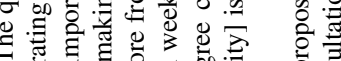

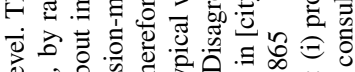

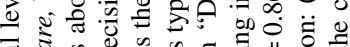

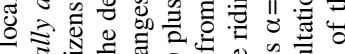

ฮ

ธ ธ ธ

。

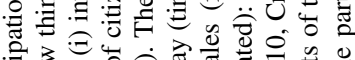

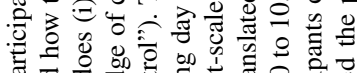

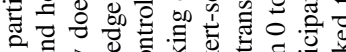

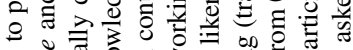

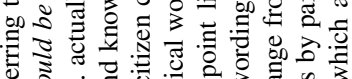

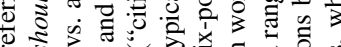

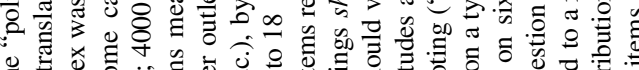

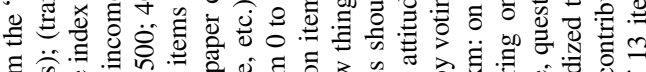

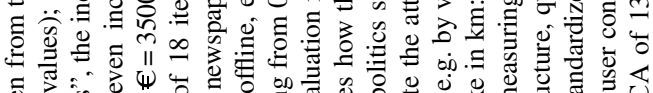
অ

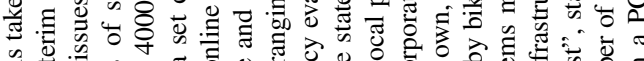
ఫ. v.

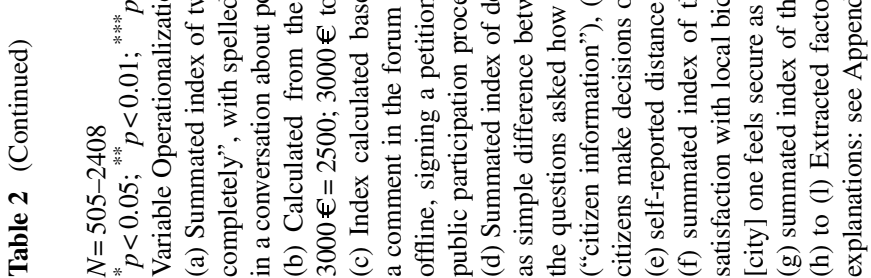


of the variables. While all of our factors are located on the individual level, we have argued that clearly the context also matters for the decision to participate. While we cannot test this in detail, we add the cities as dummy variables to the regression analysis (reflecting the different infrastructural and political contexts) to test if the city context has an influence even when controlling for other factors.

In order to test the effect of the personalized invitations, we additionally differentiate the $S_{1}$ sample by whether or not they received an invitation letter to the consultation process (treatment group vs. control group). As participation rates without a particular incentive are low, the people from the representative survey who participated in the consultation (i.e. $\mathrm{S}_{1 \mathrm{~b}}$ ) are essentially almost exclusively people from our treatment group. $90 \%$ of those received an invitation letter that acted as an extrinsic motivation to participate. Conversely, those people who registered on the site and which we surveyed with our online survey $\left(S_{2}\right)$ are all people who did not receive an invitation but were intrinsically motivated to participate. Therefore, we can use a comparison between $\mathrm{S}_{1 \mathrm{~b}}$ and $\mathrm{S}_{2}$ in order to assess differences in evaluations of the participation process and its outcomes between participants mobilised via our treatment, and self-motivated users. To this end we add a number of measures that include activity on the site, as well as participants' evaluations of aspects such as the usability and fairness of the process, or their expectations about the outcome (see Table 13 for the specific questions underlying this evaluation).

\section{Results}

\subsection{Who was mobilized?}

In order to answer our first research question on the structure of participation, we first compare the different subsamples of participants and non-participants of the consultation. A first clear difference reveals itself when it comes to the age distribution (see Table 9 in Appendix). In both participants' samples ( $S_{1 b}$ and $S_{2}$ ) the age groups of the 30-44 year olds and the 45-59 year olds are over-represented in comparison with the non-participants $\left(\mathrm{S}_{1 \mathrm{a}}\right)$. As a consequence, compared to the general population the participation processes were dominated by the 30-59 year olds. What also emerges is a picture that will repeat itself throughout the following analysis: in terms of their characteristics, the participants from the representative sample $\left(\mathrm{S}_{1 \mathrm{~b}}\right)$ that are basically mobilized via our treatment lie in between the nonparticipants $\left(\mathrm{S}_{1 \mathrm{a}}\right)$ and the registered users of the platform (from the online survey $S_{2}$ ). They are biased in a similar way as those registered participants $\left(S_{2}\right)$, but not quite to the same extent.

There is also a noticeable over-representation of men among participants (i.e. samples $S_{1 b}$ and $S_{2}$ ). Though the effect sizes of Cramers $V$ are somewhat smaller as in the case of the age distribution and not always significant, there is a clear bias towards men as these were obviously more prone to participate in the consultations than women (see Table 10 in Appendix). Partly, this result might be attributed to the fact that men are more active cyclists and therefore more likely to be recruited in a public participation process that deals with the topic of improvement of the cycling 
traffic situation in the respective city. For example, based on our representative population data, men go $6.1 \mathrm{~km}$ by bike per day and women $4.8 \mathrm{~km}$ (a difference that is significant). The second likely factor is that the participation mode has an influence on the gender distribution. The men in our representative sample are slightly more active internet users in general and especially when it comes to its instrumental deployment (in contrast to activities in online social networks), since this kind of usage is positively associated with online political participation.

Considerably stronger pronounced are the differences in highest formal education between the three groups (see Table 11 in Appendix). In the random sample of non-participants $\left(\mathrm{S}_{1 \mathrm{a}}\right)$ only $54 \%$ reached at least Abitur as their highest formal education, even though this is already a clear over-representation of 20 percentage points compared with the official census data (see Table 8 ). However, among participants this rate is much higher: $68 \%$ of participants from the representative survey $\left(S_{1 b}\right)$ had Abitur while among registered users $\left(S_{2}\right)$ this figure was even $82 \%$, therefore replicating the well-established finding that public participation efforts tend to significantly under-represent those with less formal education.

Further descriptive analysis reported in Table 2 corroborates this finding of traditional participatory inequalities. To begin with, the participants of the consultation process show considerably higher internal political efficacy $(a)$ than those who were absent. What is more, the differences in average household income $(b)$ again fit established patterns of political participation in that those who are socioeconomically better off are more prone to taking action. The overall affinity to non-institutionalized political participation that is measured by our political action scale $(c)$ reveals itself as highly differentiating between the two participant-groups $\left(S_{1 b} \& S_{2}\right)$ on the one hand and the abstainers on the other. Those who have participated in the consultation are the ones who have gathered more experience with political participation in the past and therefore accumulated more of the respective civic skills than the non-participants. Later analysis will show that these accumulated civic skills serve as a strong predictor for the probability to participate in the consultation.

The three samples exhibit the largest differences in relation to daily biking distance $(e)$ : while for participants among the representative survey respondents $\left(\mathrm{S}_{1 \mathrm{~b}}\right)$ the daily biking distance is nearly twice as high as for non-participants $\left(\mathrm{S}_{1 \mathrm{a}}\right)$, the registered online participants $\left(S_{2}\right)$ outweigh these by nearly a factor of three. We interpret this finding as a strong indicator for the relevance of personal affection for the topic of a participation process. In addition to individual resources, personal affection might be one of the main causes driving participation in the consultation process. Taking this perspective into account it is not a surprise that the group with the highest objective affection (as measured by the biking distance) is the one that is satisfied the least with the local bicycle infrastructure $(f)$. Those who are least satisfied probably see the most room for improvement. On the other hand, no significant difference between the three groups reveals itself when it comes to the evaluation of how the local administration involves its citizens in their decisions $(d)$. We take this to indicate that subject specific attitudes (i.e. cycling) outweigh generalized attitudes towards the political context as mobilizing factors for political participation.

Having in mind that the participants among the representative survey $\left(S_{1 b}\right)$ in their large majority $(90 \%)$ received an invitation letter as an extrinsic motivation to partic- 
ipate, our guess was that once they participate in the consultation, they might differ in their behaviour as well as their process perception from those who participated without invitation based on their strong intrinsic motivation, i.e. the registered participants $\left(\mathrm{S}_{2}\right)$. Indeed, we find some pronounced differences between the two groups. First of all, they differ in terms of the mere intensity of their participation $(g)$, as a summative index of proposals, comments, and ratings shows that self-recruited participants $\left(\mathrm{S}_{2}\right)$ were by far the more active group on the participation platforms. Their average number of contributions outweigh those of $S_{1 b}$ by a factor of seven.

Besides levels of activity there are differences in the evaluation of the participation process as well $(h-l)$. In particular, the perception of the quality of the produced output differs. The registered online participants $\left(S_{2}\right)$ rated the overall quality of proposals and comments that were made by other users noticeably better than those who made fewer contributions. This tendency to a more positive evaluation of the participation process by the registered participants $\left(S_{2}\right)$ is also reflected in the average values concerning the fairness and the exclusive online mode of the consultation process-though it is unclear at this stage if this more positive outlook in general is due to the fact that respondents from $S_{2}$ had taken part in the consultation process based on intrinsic motivation (while the respondents from $S_{1 b}$ were mobilized by extrinsic factors to a higher degree) or simply due to the higher involvement by the $\mathrm{S}_{2}$-respondents.

To conclude our findings of the comparison between those who have participated in the consultation and those who have not, we notice that the previously reported differences are replicated. Those who are already better off socioeconomically are profoundly more likely to participate in a consultation process such as this consultation on cycling matters. However, we also notice a pronounced tendency that in nearly every aspect, consultation participants from the representative survey $\left(\mathrm{S}_{1 \mathrm{~b}}\right)$ lie in between the non-participants $\left(\mathrm{S}_{1 \mathrm{a}}\right)$ and those participants who registered on the online-platform $\left(S_{2}\right)$. This result suggests that $S_{1 b}$ primarily consists of respondents who reacted directly to our invitation letter and would not have participated without it. Before we dig deeper into this particular phenomenon, we will turn to our second research question on why people did (not) participate online and elaborate on the reasons why the consultation failed to mobilize the large majority of citizens to participate.

\subsection{Who was (not) mobilized?}

Since our data from the representative surveys $\left(\mathrm{S}_{1}\right)$ includes respondents who have heard of the consultation process but still decided not to take part, we collected their responses concerning the reasons for their absence. In this sub-sample $\left(S_{1 c}\right)$ the most common reason for not taking part (cited by almost every third respondent) was a lack of confidence that such a consultation process might be effective to improve the conditions of the local bicycle infrastructure (see Table 3). Interestingly enough these doubts concerning the effectiveness of the consultation process are to a considerable degree shared also by those who actually have participated (see Table 13 in Appendix). However, 20\% of the respondents who have heard about the consultation but did not take part answered that they are genuinely not interested 
Table 3 Reasons for absence from consultation (multiple responses in \%)

\begin{tabular}{ll}
\hline & $\mathrm{S}_{1 \mathrm{c}}$ \\
\hline Effectiveness doubts & 29 \\
Not interested & 20 \\
Categorically against online participation & 14 \\
Already satisfied with discussion & 11 \\
Unclear goals of participation process & 10 \\
Concerns with data security & 7 \\
Technical Problems & 6 \\
Deployed other channels & 5 \\
No need for improvement & 4 \\
\hline
\end{tabular}

$(N=567)$

in the topic, and another $14 \%$ of these respondents are opposed to online forms of political participation.

As the question enquiring about reasons for abstaining from the consultation allowed for multiple responses, we were interested if some of the multiple response patterns are common enough that they form underlying dimensions. The principal component analysis of these multiple response combinations results in four different dimensions (see Table 12 in Appendix). These are:

A. public participation distrust (including effectiveness doubts, and a lack of clarity concerning the goals of the consultation)

B. aversion against the online mode of the participation (including technical problems, concerns with data security, and being categorically against online participation),

C. a response pattern suggesting a passive interest (correlating positively with the satisfaction with the ongoing discussion and negatively with the "no interest" item), and

D. a pattern that suggests that the reason for abstaining was the perception that there is no problem left to be solved (including "no need for improvement" and, negatively, the deployment of other channels).

The four components explain about $54 \%$ of the variance in the item-set and can therefore be regarded as a reasonable approximation of the underlying correlationmatrix. It is worth pointing out, that the three most common reasons for absence are each located on a different factor, or in other words: when a respondent mentioned "effectiveness doubts" as a reason for abstaining it becomes less probable that he also mentioned a lack of interest or that he is categorically against online participation. This result leads to the conclusion that these reasons for absence are truly genuine and do not form a kind of syndrome of a generalized aversion against (online) participation.

When investigating mechanisms of engagement, of further interest are potential differences in the information flow between the three groups who have at least heard of the consultation $\left(S_{1 b}, S_{1 c}\right.$, and $\left.S_{2}\right)$, namely the points of contact with information about the online dialogue as reported in Table 4 . These numbers could reveal which strategy is the most fruitful when it comes to mobilize for a participation endeavour. 
Table 4 Point of contact with consultation by sample (multiple responses in \%)

\begin{tabular}{llll}
\hline & $\mathrm{S}_{1 \mathrm{~b}}$ & $\mathrm{~S}_{1 \mathrm{c}}$ & $\mathrm{S}_{2}$ \\
\hline Newspaper, Radio, TV, Internet & 44 & 58 & 44 \\
Personal Invitation & 25 & 18 & 1 \\
Social Media & 19 & 6 & 18 \\
$\begin{array}{l}\text { Companion, Friends, Acquain- } \\
\text { tances, Colleagues }\end{array}$ & 18 & 14 & 27 \\
Online-Newsletter & & & \\
Outdoor Advertising & 11 & 3 & 13 \\
Information Event & 13 & 8 & 7 \\
$(N=)$ & 5 & 1 & 4 \\
\hline
\end{tabular}

For all three groups the media (newspaper, radio, TV, Internet) is the most often mentioned source of information. This finding fits our observation that in the course of the participation process the platforms were significantly higher frequented immediately after the respective local newspapers had reported about the consultations. In our control group which did not receive the personalized invitation, $63 \%$ would find out about the online consultation via the media. For those receiving an invitation it was significantly less with $52 \%$. Beyond this, there are few differences between control and treatment group.

However, as this data is based on subjective retrospection, its validity is questionable. For example, only $25 \%$ of the respondents in the $\mathrm{S}_{1 \mathrm{~b}}$-sample mention the "personal invitation" letter as a point of contact, but our data reveals that actually $90 \%$ of them received such a letter. The reason for this lack of validity surely is the period of time between the execution of the consultation processes and the start of our surveys which amounted to about nine months. This was because we would not have been able to ask for attitudes towards the consultation process at least until the respective final reports were published which took about half a year after the participation phases were closed. So it is highly probable that instead of accurately recalling their point of contact with information about the consultation, the respondents made use of heuristics that rather represent their individual patterns of usual information flows. As such, the data do not completely lack informational value, since the responses might shed light on how the respondents usually hear of such events, which is nevertheless viable information for future decisions on which channels should be chosen for mobilization purposes.

As should be expected, $S_{1 b}$ (in which $90 \%$ received our personalized invitation) and the registered participants $\left(\mathrm{S}_{2}\right)$ who did not receive such an invitation do indeed differ on this point $(25 \% \text { vs. } 1 \%)^{1}$. Therefore, irrespective of poor recall, we might detect an effect of the field-experiment on mobilization based on our data. This and other determinants will be discussed in the following section.

\footnotetext{
1 It is important to note that the online survey among the registered users of the consultation started with a screening question in which the respondents were asked if they had received an invitation to our representative survey before (which would make them belong to our $S_{1}$ sample to which also the invitation letters were sent out exclusively). If they answered with yes, they were requested to leave the survey and to follow the link that led to our representative survey.
} 


\subsection{Determinants of mobilization and effects of experimental treatment}

In order to test the mobilizing effect of a personalized invitation for our third research question, in each city a random selection of citizens received letters informing them about the ongoing consultation process in the respective city. Due to the different ratios between control and treatment groups, in the end $71 \%$ of the cumulated sample $\left(S_{1}\right)$ received this invitation. Table 5 provides a first hint to the effect of the mobilization treatment. While $7 \%$ of the treatment group participated actively and an additional $5 \%$ of them passively, only $3 \%$ (1\% actively, and 2\% passively) of the control group took part in the consultation. About half of the treatment group but three quarters of the control group responded that they had not even heard of the consultation process. This difference between groups is statistically significant. Even though the majority of respondents who received an invitation letter still responded that they had not heard of the consultation (see discussion in the previous section), there clearly is a sizeable and significant effect of the treatment.

But how big is this effect compared to other factors? To answer this question, we make use of a binary logistic regression analysis (see Table 6). Based on the representative sample $S_{1}$, our dependent variable is whether respondents took part in the consultation or did not. To provide further insights we differentiate between those who participated actively and those who only visited the online platform to get an idea of the ongoing discussion but did not contribute any content (proposals, comments and/or ratings). As defined above, these participants are therefore counted as passive participants.

Comparing these two subgroups, in the first regression model (1) the dependent variable is operationalized as active and passive participation (=1) vs. abstaining $(=0)$ while the second regression model (2) estimates the effects of the predictors on the probability of participating actively only $(=1)$ in the consultation process (vs. others $=0$ ). As predictors we integrate the factors introduced above with a few exceptions. Thus, we decided to calculate the analysis without household income as a predictor, since this variable - as always in survey research (see e.g. HoffmeyerZlotnik and Warner 1998) - suffers from a high proportion of missing values and therefore would have shrunk the "participated" category of our dependent variable

Table 5 Participation in consultation by experimental group (in $\%)$. (Source: Sample $\mathrm{S}_{1}$ )

\begin{tabular}{lll}
\hline & $\begin{array}{l}\text { Control } \\
\text { group }\end{array}$ & $\begin{array}{l}\text { Treatment } \\
\text { group }\end{array}$ \\
\hline Actively participated & 1 & 7 \\
Passively participated & 2 & 5 \\
Not participated but heard of it & 22 & 31 \\
Not heard of it & 75 & 57 \\
$(N=)$ & 100 & 100 \\
& $(577)$ & $(1426)$ \\
\hline
\end{tabular}

Cramers V=0.187 $(p<0.001)$ 
Table 6 Determinants of participation in consultation (logistic regression). (Source: Sample $\mathrm{S}_{1}$ )

\begin{tabular}{|c|c|c|c|c|}
\hline & \multicolumn{2}{|c|}{ (1) Passively \& Actively Participated } & \multicolumn{2}{|c|}{ (2) Actively Participated } \\
\hline & Wald & $\operatorname{Exp}(b)$ & Wald & $\operatorname{Exp}(b)$ \\
\hline$\overline{\text { Constant }}$ & $96.772^{\text {*** }}$ & & $49.467^{* * *}$ & \\
\hline \multicolumn{5}{|l|}{ Age groups } \\
\hline (Reference: 18-29) & $11.561^{* *}$ & & $17.329^{* *}$ & \\
\hline $30-44$ & $9.428^{* * *}$ & 2.793 & $6.613^{*}$ & 2.820 \\
\hline $45-59$ & $9.181^{* *}$ & 2.722 & 3.772 & 2.192 \\
\hline $60+$ & $4.207^{*}$ & 2.032 & 0.192 & 0.816 \\
\hline \multicolumn{5}{|l|}{ Gender } \\
\hline Female & 0.245 & 0.911 & 0.547 & 0.844 \\
\hline \multicolumn{5}{|l|}{ Education } \\
\hline Abitur or higher & 2.226 & 1.348 & 3.646 & 1.769 \\
\hline \multicolumn{5}{|c|}{ Internal Political Efficacy } \\
\hline (Reference: 0-5) & 0.437 & & 1.050 & \\
\hline $6.25-7.5$ & 0.367 & 0.877 & 0.759 & 1.328 \\
\hline $8.75-10$ & 0.349 & 0.866 & 1.011 & 1.424 \\
\hline \multicolumn{5}{|l|}{ Political Action Scale } \\
\hline (Reference: 0-1) & $29.371^{* * *}$ & & $18.257^{* * *}$ & \\
\hline $2-4$ & 2.121 & 1.671 & 3.639 & 7.165 \\
\hline $5-7$ & $4.680^{*}$ & 2.183 & $4.893^{*}$ & 9.805 \\
\hline $8+$ & $16.842^{* * *}$ & 4.395 & $8.039^{* *}$ & 18.620 \\
\hline \multicolumn{5}{|l|}{ Daily biking distance } \\
\hline (Reference: $0 \mathrm{~km}$ ) & $40.651^{* * *}$ & & $38.243^{* * *}$ & \\
\hline $0.25-4.5 \mathrm{~km}$ & 1.610 & 1.419 & 0.937 & 1.570 \\
\hline $5-9.5 \mathrm{~km}$ & $16.036^{* * *}$ & 2.890 & $13.218^{* * *}$ & 4.839 \\
\hline $10+\mathrm{km}$ & $29.110^{* * *}$ & 3.973 & $21.705^{* * *}$ & 7.241 \\
\hline \multicolumn{5}{|l|}{ City } \\
\hline (Reference: Bonn) & 1.938 & & 5.361 & \\
\hline Ehrenfeld & 0.447 & 0.879 & 1.708 & 0.724 \\
\hline Moers & 1.910 & 0.727 & $4.786^{*}$ & 0.447 \\
\hline Treatment & $30.315^{* * *}$ & 4.176 & $20.197^{* * *}$ & 6.992 \\
\hline $\begin{array}{l}\text { Pseudo- } R^{2} \text { (Nagelk- } \\
\text { erke) }\end{array}$ & 0.179 & & 0.277 & \\
\hline
\end{tabular}

$N=1894$

$* p<0.05 ; * * p<0.01 ; * * * p<0.001$

Variable Operationalization: see Table 2 
even further. For similar reasons we decided to exclude satisfaction with the bicycle infrastructure, and local democracy evaluation ${ }^{2}$.

Looking at the results, the effect patterns of the two regression models are quite similar: holding all other factors constant again the two age-groups of 30-44 year olds and 45-59 year olds are more prone to take part in the consultation process than younger and older age groups. This is true for both regression models. Due to the smaller number of cases in the participation-category of the dependent variable in the second regression model, here only the effect of the 30-44 year olds category is significant, while in the first model all older age groups differ significantly from the reference category of 18-29 year olds. With effect sizes (odds ratios) between 2.0 and 2.8 for the older age groups the propensity of the youngest to participate in this consultation process was considerably lower compared to the other age groups. Though our bivariate analysis showed significant effects of gender, education, and internal political efficacy on our dependent variable, these findings cannot be replicated on the multivariate level: in both regression models none of these predictors remains significant. Their effects are absorbed by the political action scale as a mediator variable. The categories of the political action scale unfold significant effects in both regression models for those who were politically very active (5-7 instances and $8+$ instances) in the preceding twelve months. The effect sizes reach from odds ratios of 2.2 (5-7 instances) to 4.4 (8+ instances) in the first regression model and even from 9.8 (5-7 instances) to 18.6 ( $8+$ instances) in the second regression model. The respondents' daily biking distance (as a measure of topic-affection) also has pronounced influences. Compared to those who do not travel by bike at all, respondents whose daily distance is between 5 and $9.5 \mathrm{~km}$ are 2.9 times (model 1) and 4.8 times (model 2) more likely, and respondents whose daily biking distance is $10 \mathrm{~km}$ or higher are even 3.97 times (model 1) and 7.2 times (model 2) more likely to have participated in the consultation.

Holding all other factors constant, the city itself where the consultation process took place only has a significant effect in model 2: in Moers the respondents were only half as likely to participate actively compared to the residents of Bonn. Whether this effect is due to city-specific differences in the need for improving the local bicycle traffic infrastructure or to differences concerning the promotion of the consultation is a question that is not accessible by the means of our empirical data, unfortunately.

Coming to the last predictor in our models representing the experimental treatment, the effect of the invitation letter is quite impressive. Those who received an invitation are 4.2 times (model 1) and nearly 7 times (model 2) more likely to report participation in the consultation than those who did not receive this kind of incen-

\footnotetext{
2 To justify this we conducted an additional regression analysis in which we integrated all these variables. Here the satisfaction with the local bicycle infrastructure mediated some of the effects of the daily biking distance. However, the informative value of this effect did not compensate for the loss in number of cases, since only those who at least sometimes travel by bike were asked to rate the local bicycle infrastructure. Also, the democracy evaluation-index did not have any significant effects on the probability to participate in the consultation. We can therefore conclude that in matters of serving as a mobilizing factor, "objective" topic-specific affection outweighs both the topic-specific satisfaction and the more general attitudes towards the way local institutions handle public demand.
} 
tive. In other words, the treatment is, in its relative relevance, comparable to factors like high topic-related affection and-when the operationalization of the participation includes the passive participants - a general high participation affinity; though in the second regression model the latter factor stands out as the most profound predictor.

Comparing the two operationalizations of participation in the two regression models (model 1 vs. model 2), all in all the effects of the predictors are quite similar in both regression models, but noticeably more pronounced where we only include those participants who took part in an active way and contributed proposals, comments, and/or ratings to the online discussion. These more pronounced effects also result in a higher ratio of explained variance with a Pseudo- $\mathrm{R}^{2}$ (Nagelkerke) of 0.277 in the second model compared to only 0.179 in the first.

In order to clarify the mechanisms by which citizens become engaged, we investigated also what determines if people have heard about the consultation, because only those who heard about the consultations are potential participants. The results of this regression analysis, that used the same predictors as above, indicates that knowledge about the consultation is basically equally distributed across social groups. For more details refer to Table 15 in the Appendix.

Given this, the result of the second analysis is hardly surprising; it is based solely on respondents who had at least heard of the consultation process as this mitigates the effects introduced through a lack of knowledge. This replicates the results shown in Table 6 with a slight reduction of the influence of the field experiment and a slight increase in overall explained variance.

\section{Discussion}

What do these results imply for our research questions? First of all, we were interested in (i) who participates in opportunities for political online participation. Our surveys of the participants of the consultation confirm the findings of biases that were reported from previous research into local participation in general (Einstein et al. 2019; Michels and de Graaf 2010) and that are exacerbated when participation moves online (Aichholzer et al. 2016; Escher 2013). Therefore, people with a high socioeconomic status were over-represented, in particular men and those aged 45-59 years old. Those who decided to engage in the consultation without any particular invitation are already politically active and possess high internal efficacy. They were primarily motivated by their interest in the topic, given that as avid cyclists they are particularly affected by the topic of the online consultation. Not only this, they were also particularly dissatisfied with the cycling infrastructure in the city. This confirms results of previous research that also found a higher propensity of dissatisfied citizens to engage in local consultations (Einstein et al. 2019; Schneider 2018). Note, however, that the motivating factor is issue-specific dissatisfaction, not dissatisfaction with local politics per se. As such our findings differ from Ritzi and Wagner (2016) who found that dissatisfaction with democracy leads to more engagement online. This difference could be because the authors focused on young people (22-35 years old) or because they investigated online political participation 
in general. It could well be that for institutionalized top-down participation such (dis)satisfaction with local politics has no particular motivating effect.

That previous political activity and issue concern are by far the most important factors explaining participation is also confirmed by a logistic regression that controls for correlations between these variables which are for example strong in the case of education and age as well as efficacy. Interestingly, while online forms of political participation tend to increase engagement of young people (Escher 2013) we do not find this effect here. It could be that younger people would tend to favor noninstitutionalized forms of political participation via other online channels (such as social media) instead of a consultation platform, or that the topic of cycling tends to be of less interest to young people. This points to the fact that the issue at stake in such a consultation does determine to some degree the socioeconomic characteristics of the participants. The better educated citizens tend to be the keener cyclists ${ }^{3}$ and hence participate more often in this consultation. A debate on social benefits or council housing might also motivate some other parts of the population.

Overall, what the survey shows is that those who do not participate belong to the commonly less active parts of the population. This applies for example to the young and the pensioners and those with lower education and less income. In particular, those not participating report lower levels of self-efficacy. These findings point to the possibility of an over-representation of attitudes and knowledge that are held by those who are better off socioeconomically and who tend to live in areas that are already better equipped with cycling infrastructure. The "upper-class" bias in this consultation process could harm those who have the greatest need to improve their local infrastructure as their views are less well represented.

This leads to the second research question, namely (ii) why do people (not) participate online. The primary reason for not participating is the lack of knowledge about the online consultation in the first place. While this does not come as a surprise, our research allows us to put a number on the magnitude of this barrier to participation. With the common advertisement strategies by the local governments, three quarters of the population (here: our control group) did not hear about the process and hence never had a chance to participate. However, our results show that at least this knowledge is mostly socially equally distributed so that with the exception of older people (which we take to be keener recipients of newspapers) all social groups within a given city were equally likely to know about the process. In other words, the distribution of knowledge is not the cause for the participatory biases.

Our data demonstrates that established media sources (no matter whether online or offline) remain the single most important source of information about such an online consultation. In our case, $63 \%$ of the control group indicated that this is the way they found out about the process, followed by friends' recommendations and social media. Even though recall is prone to errors, it is obvious that the usual engagement strategies for such forms of online participation are limited in their ability to reach the wider population. Our findings confirm the continuing relevance of traditional media for stimulating online engagement that has been reported more

\footnotetext{
3 The original formal education variable (ordinal, 5 values) and the categorized daily biking distance (see Table 6) correlate with rho $=0.244$ (non-parametric correlation, $\mathrm{p}<0.001$ ).
} 
than a decade ago (Kubicek et al. 2009; Kubicek and Westholm 2010). This could also be a reason why we did not find that knowledge was unevenly distributed as Escher and Riehm (2017) observed for knowledge about the German Bundestag's petitions process. We might hypothesize that the latter is knowledge gained through political socialization while information on the online consultation was basically local news. While diffusion of information on consultation via news media was low, this news coverage is likely less socially biased than other information sources.

Nevertheless, a sizeable share of the population had heard about this process and with our experiment we also made sure that this knowledge would be equally distributed among the local population. So for those who knew about the process, what were the reasons not to participate? When asked about their reasons, a quarter plainly stated not to be interested. This self-assessment is also supported through additional survey evidence. Those abstaining reported significantly higher satisfaction with the bicycle infrastructure as well as substantially (and significantly) less cycling activity, both making a lack of interest in the topic of the online consultation plausible.

Four different motives for abstention emerge. The most important is doubts about the effectiveness of the process and its goals. Our results show that there was a great potential for higher participation in the consultation that was not fully exploited, as one in three abstainers mentioned at least one of these reasons. While those who are simply not interested might be mobilized for other topics, first and foremost the effectiveness doubts might be worthwhile to address in future participation endeavours. They point in a direction of pessimism about the responsiveness of public authorities that is not topic-dependent but universal. Keeping in mind that negative public assessments of the performance of public authorities have been one of the motivations to increase opportunities for participation, it should be a cause of concern that a sizeable share of the population remains sceptical about the prospects of change through such means.

While this is an issue for all forms of top-down participation, a second important factor relates specifically to online participation as about one in five people are opposed to online means of participation, had technical problems or reservations about data privacy. This acts as an important reminder that the barriers to online participation are not simply overcome through enlarging access to the Internet (Schöttle 2019). At the same time, it is important to highlight that abstention does not always equal dissatisfaction or lack of resources. So indicated more than ten percent that they were already satisfied with the discussion; and a few also saw simply no need for improvement in cycling infrastructure. Finally, 5\% said they had used other means to influence cycle planning.

In order to contribute solutions to the problem of low and biased participation, our third research question tested a particular mobilization strategy, namely (iii) how effective personalized invitations are to increase and diversify participation. Indeed, our randomized-controlled field experiment shows a clear mobilizing effect in that those receiving a personal invitation are about five times more likely to participate compared to those not receiving an invitation. Expressed in numbers, while through the standard means of advertisement only $3 \%$ of the population at least visited the consultation platform, this number rose to $12 \%$ in the group receiving the invitation. 
The effect is even stronger when considering only those actively engaging in the consultation via proposals, comments or ratings. Here, the invitation increases the rate of active participation from $1-7 \%$, in other words increasing by a factor of 7 . To put this in perspective, for our wide definition of participation (including both active and passive participation) the effect size is about as big as that of the other two important motivating factors we discussed above, namely interest in the topic and previous political activity. Only for those engaging actively on the site is previous political activity an even stronger predictor.

We also investigated what we believe is a so far little researched question, namely (iv) how do those mobilized differ in their attitudes and activities from those who become engaged without particular stimuli? What our results show is that differences can be observed both in terms of the sociodemographic profile and the attitudes towards the online consultation. Turning first to the demographic profile, those who became mobilized in response to our personal invitation are still people that are already politically active and hence biased in the ways described above, yet these biases are somewhat less pronounced. In other words, the invitations would entice in particular more women but also some more pensioners, more people without Abitur and people with somewhat lower self-efficacy to decide to participate. Therefore, not only is this strategy effective in getting people to engage that would otherwise not have done so-also at least some of these people are from usually under-represented backgrounds.

Differences can not only be observed in terms of sociodemographic characteristics but also in terms of attitudes. First of all, the personal invitation mitigates the strong issue salience of the consultation. While the heavy cyclists who are dissatisfied with the infrastructure would find their way to the online consultation without help, the invitation also brings people to the process who are not motivated through dissatisfaction. Second, it also convinces those people to participate that have reservations about online participation. However, when those invited do participate, they are significantly less active as measured in number of proposals, comments or ratings (those invited made on average 2.2 contributions (proposals, comments or ratings), while those registered on the site made 15.3 contributions). Yet it is important to note that the invitation letters were sent out two weeks after the respective process had started. Beside a narrowed timeframe, the fact that by this time many problems had already been highlighted in the proposals made by other participants on the respective platform might have discouraged newly arrived users to participate more extensively.

Those mobilized through personalized invitation differ also in their assessment of the process. Interestingly, they evaluated the quality of the output (i.e. the other participants' contributions) as lower than the self-motivated participants. Given that the quality was judged as very high by the local planning officials as well as the research team, we take this finding as evidence that those mobilized participants were not able to get a full picture of the activity on the platform, in part because they spent so little time on it. What is more, it might also be affected by their generally more negative attitude towards online political participation, even though they still rated usability as high as the other participants. What all participants-either intrinsically or extrinsically motivated-agree on is their pessimistic outlook in terms of the 
actual substantial consequences from the online consultation. Again, this does not bode well for proponents of participation as a means to increase specific political support.

Our research has a number of important implications for those practitioners in local government as well as respective participation service providers who are tasked with organizing such consultations both online and offline. For them, the recurring challenge is to stimulate enough engagement amongst the public in order to produce actual results. While it will come as little news to them that those affected by the issue at stake are most easily convinced to engage (in our case, those avid cyclists), we could show that with the traditional means of mobilization such as adverts, kickoff events or distributing newsletters only about a quarter of the population could be reached. What is more, we could show that personalized invitations can be a means to increase this knowledge as these had a sizeable mobilization effect. Our research design makes it possible to actually put a number to the size of this effect, which we estimate roughly with a factor of four to seven for at least visiting the site or active participation respectively. In other words, all else being equal a personal invitation letter increases a random person's chances of active participation sevenfold-even if often they will not even actively remember having been invited. What is more, while this tends to engage the parts of the population already active, in our example those who were mobilized were less dissatisfied with the existing infrastructure, in other words this personalized invitation could help to reach out beyond the very critical citizens (who tend to be mobilized out of their dissatisfaction) to those tending somewhat more to the population average. The other important source of mobilization is media coverage which also has a high influence on engagement.

\section{Conclusion}

Our research aimed to investigate who participates in opportunities for online participation provided by local authorities and which mechanisms explain the individual decision to engage or abstain. While our research has confirmed that participants in local online consultations are usually middle-aged men characterized by a high level of political activity and resources (in terms of education and income as well as internal efficacy), our research has made several important contributions to highlight the underlying reasons. First of all, our research allowed us to establish how knowledge about opportunities for participation is distributed. We could show that with the commonly applied strategies local governments managed to inform only about a quarter of the population, but at least this knowledge (or lack thereof) is more or less evenly distributed across the different social groups. The main sources of information are still established news media, followed by friends' suggestions and social media mentions.

Second, we were able to enquire in detail about the motivations for participation vis a vis abstention. Our results show that dissatisfaction with local government as such neither motivates to participate nor dissuades people from engagement. Instead it is issue-specific affection (in our case: being keen cyclists) and dissatisfaction (in our case: being particularly dissatisfied with the cycling infrastructure) that would 
act as the main motivation to engage in the online consultation. In contrast, the main reasons to abstain are doubts about the effectiveness of public participation and lack of interest. Two findings are particularly noteworthy. On the one hand, despite the expectations regarding online participation cited earlier, we show that these new online means also introduce additional participation barriers that exclude certain groups, as about one in five people surveyed would name concerns against the technology or related data protection as reasons not to participate. On the other hand, we could show that abstention can not only be caused by barriers but also by satisfaction. About one in nine non-participants would remain inactive because she was already satisfied with the discussion with nothing to add. In other words, a low participation rate does not only signal doubts or dissatisfaction but can at least to some degree also be explained by satisfaction with the existing process.

Third, via a randomized-controlled field experiment we could empirically test the effects of personalized invitations as an effective strategy to mobilize participation that increased the participation rate by a factor of between four and seven. As a matter of fact, this strategy rivals issue-specific motivation mentioned above as the main motivation for participation. What is more, our results also unearthed differences between the intrinsically motivated and (through a personalized invitation) mobilized participants in terms of the sociodemographic profile as well as the attitudes towards the online consultation. Not only does this mobilization strategy help to reach out to some commonly under-represented groups (in particular women but also some pension-age citizens and those without Abitur), it also convinces people to participate who are not as much motivated by being affected and dissatisfied with the issue at stake and as such introduce opinions closer to the median citizen.

These findings have important implications for researchers and practitioners alike interested in increasing equality in participation and particularly in addressing the well documented biases of political participation online. That knowledge is not socially biased is good news even though the share of the population is still too small. Our findings suggest that both conventional media as well as personalized invitations can be effective strategies to increase both knowledge and participation. Key is highlighting how each and every one is personally affected by the issue under consultation, as this was shown to be the main driver of engagement. Information on consultations should also specifically address concerns about the effectiveness in general and the technology in particular as both were main reasons to abstain from participation. Yet even with such measures in place it needs to be acknowledged that there will be clear limits in who can be mobilized to participate.

Notwithstanding these contributions, we have to acknowledge a number of limitations. First of all, our information about the participants is almost exclusively based on those people registering on the site and those who were mobilized by our invitation. In contrast, the comparatively small size of the control group in combination with the generally minority participation rate (overall just about $1 \%$ of the population would participate actively) does not allow us to make inferences about those people who take part in online consultations without registering on the site. These account for a substantial amount of contributions (around 35-45\% in our cases) and it can be assumed that they differ in their sociodemographic profile and activity from those people who make the effort to register. Other questions that we 
will turn to in further investigations are: (i) The more subtle differences between the cities, for example why was engagement in Moers lower than in the other cities, or why was Bonn more effective in informing citizens about the process. (ii) What are the differences between the samples, e.g. why is it that women get equally well mobilized through the invitation letters but not those with other characteristics. (iii) What are the methodological issues arising from the low recall of the personalized invitation that puts into question some of the other retrospective measures used in (our) surveys.

Finally, future research should aim to test other engagement strategies using randomized-controlled designs such as different ways of traditional advertising or mobilization effects of networks of organized interests. Also, as mentioned above, it would be very useful to learn more about the differences in characteristics, attitudes and behavior between participants who register with an online platform (usually with a pseudonym) and those who use it completely anonymously.

Funding This research was funded by the Strategic Research Fund of Heinrich Heine University Düsseldorf. In addition, this work has benefited from financial support provided by the Düsseldorf Institute for Internet and Democracy as well as two workshops funded by the Center for Advanced Internet Studies (CAIS).

Funding Open Access funding provided by Projekt DEAL.

Open Access This article is licensed under a Creative Commons Attribution 4.0 International License, which permits use, sharing, adaptation, distribution and reproduction in any medium or format, as long as you give appropriate credit to the original author(s) and the source, provide a link to the Creative Commons licence, and indicate if changes were made. The images or other third party material in this article are included in the article's Creative Commons licence, unless indicated otherwise in a credit line to the material. If material is not included in the article's Creative Commons licence and your intended use is not permitted by statutory regulation or exceeds the permitted use, you will need to obtain permission directly from the copyright holder. To view a copy of this licence, visit http://creativecommons.org/licenses/by/4. $0 \%$. 


\section{Appendix}

\section{Summary of online consultations and associated surveys}

Table 7 Overview about the three online consultations

\begin{tabular}{|c|c|c|c|}
\hline Name & $\begin{array}{l}\text { Bonn } \\
\text { Bonner Rad-Dialog }\end{array}$ & $\begin{array}{l}\text { Ehrenfeld } \\
\text { (Cologne) } \\
\text { Ehrenfelder } \\
\text { Raddialog }\end{array}$ & $\begin{array}{l}\text { Moers } \\
\text { Moerser Raddialog }\end{array}$ \\
\hline Inhabitants & About 300,000 & $\begin{array}{l}\text { About } 100,000 \\
\text { (about } 1 \mathrm{~m} \text { in } \\
\text { Cologne in total) }\end{array}$ & About 100,000 \\
\hline $\begin{array}{l}\text { Previous } \\
\text { online con- } \\
\text { sultation } \\
\text { offers by city }\end{array}$ & Regularly & Rarely & None \\
\hline \multicolumn{4}{|c|}{ Participation process } \\
\hline Start date & 13.09.2017 & 20.09.2017 & 14.09 .2017 \\
\hline $\begin{array}{l}\text { Letters sent } \\
\text { out inviting } \\
\text { to consulta- } \\
\text { tion }\end{array}$ & 4000 & 1667 & 1667 \\
\hline Other PR & $\begin{array}{l}\text { Posters and advertisements on } \\
\text { public screens, public kick-off } \\
\text { event, press releases, notification } \\
\text { of cycle-relevant stakeholders }\end{array}$ & $\begin{array}{l}\text { Press release, } \\
\text { notification of } \\
\text { cycle-relevant } \\
\text { stakeholders }\end{array}$ & $\begin{array}{l}\text { Press conference on } \\
\text { kick-off, press release, } \\
\text { notification of cycle- } \\
\text { relevant stakeholders }\end{array}$ \\
\hline End date & 18.10 .2017 & 24.10 .2017 & 19.10.2017 \\
\hline $\begin{array}{l}\text { Date of final } \\
\text { report }\end{array}$ & 20.04 .2018 & 17.05 .2018 & 01.06 .2018 \\
\hline \multicolumn{4}{|c|}{ Data collection } \\
\hline \multicolumn{4}{|c|}{ Population survey } \\
\hline Pre-process & $\begin{array}{l}N=1.640 \\
(34 \% \text { of } 4.853) \\
10.08 .-13.09 .2017\end{array}$ & None & None \\
\hline Post-process & $\begin{array}{l}N=778 \\
(71 \% \text { of } 1.094) \\
16.05 .-30.06 .2018\end{array}$ & $\begin{array}{l}N=625 \\
(27 \% \text { of } 2.289) \\
05.06 .-31.07 .2018\end{array}$ & $\begin{array}{l}N=690 \\
(29 \% \text { of } 2.342) \\
02.06 .-31.07 .2018\end{array}$ \\
\hline $\begin{array}{l}\text { Online } \\
\text { survey of } \\
\text { registered } \\
\text { participants }\end{array}$ & $\begin{array}{l}268 \\
(45 \% \text { of } 595)\end{array}$ & $\begin{array}{l}65 \\
(47 \% \text { of } 137)\end{array}$ & $\begin{array}{l}61 \\
(47 \% \text { of } 131)\end{array}$ \\
\hline
\end{tabular}

All groups were surveyed at considerable distance from the end of the consultation phase to allow for publication of the final project report that summarized the main findings from the consultation phase, and to provide local politics and administration with some time to process these and give them an opportunity to provide a first response

a Participants were free to register. Proposals and comments could be made anonymously, only rating of proposals required registration 


\section{Composition of survey samples}

In comparison with the official data, especially the younger and the less educated are under-represented in the samples from all three cities, while on the other hand the gender ratio is quite accurate. In Bonn this bias is even more pronounced since we make use of the data of the second wave of a panel design, causing a second and third "filtering process". Supposedly primarily those who are interested at least to some extent in the topics of the first questionnaire agreed to be contacted again, and of those again a subset of individuals whose interest and motivation were high enough responded to the second wave of the survey eventually. To put this into perspective: while in the first wave the percentage of respondents with at least Abitur was "only" 19 percentage points higher than in the living population, in the second wave this gap increased to $31 \%$.

Table 8 Comparison of age, education and gender in surveyed samples from Bonn, Cologne, and Moers with official 2011 census data from the respective cities (in \%)

\begin{tabular}{lllllllll}
\hline & Bonn & \multicolumn{3}{c}{ Cologne } & Moers & & Total \\
& Sample & Census & Sample & Census & Sample & Census & Sample & Census \\
\hline Age: $18-29$ & 15 & 21 & 15 & 20 & 11 & 16 & 14 & 20 \\
Age: $30-44$ & 21 & 36 & 28 & 38 & 18 & 32 & 22 & 37 \\
Age: $45-59$ & 31 & 21 & 27 & 21 & 31 & 26 & 30 & 21 \\
Age: $60+$ & 33 & 22 & 31 & 21 & 40 & 26 & 35 & 22 \\
Education: & 72 & 41 & 54 & 32 & 32 & 16 & 53 & 32 \\
Abitur & & & & & & & & \\
Gender: Female & 54 & 53 & 54 & 52 & 50 & 53 & 53 & 52 \\
$(N=)$ & $(778)$ & & $(625)$ & & $(690)$ & & $(2093)$ & \\
\hline
\end{tabular}

This comparison includes the whole sample from the representative survey, not just those respondents for which information about their engagement with the consultation platform is available as reported in Table 1 


\section{Distribution of sociodemographic characteristics of respondents}

Table 9 Age distribution by sample (in \%)

Table 10 Gender by sample (in \%)

Table 11 Highest formal education by sample (in \%)

\begin{tabular}{llll}
\hline & $\mathrm{S}_{1 \mathrm{a}}$ & $\mathrm{S}_{1 \mathrm{~b}}$ & $\mathrm{~S}_{2}$ \\
\hline $18-29$ & 14 & 7 & 10 \\
$30-44$ & 22 & 28 & 30 \\
$45-59$ & 29 & 38 & 43 \\
$60+$ & 36 & 27 & 17 \\
$(N=)$ & 100 & 100 & 100 \\
& $(1746)$ & $(191)$ & $(355)$ \\
\hline
\end{tabular}

Cramers $\mathrm{V}_{\text {total }}=0.128(p<0.001)$

Cramers $\mathrm{V}_{\mathrm{S} 1 \mathrm{a} \times \mathrm{S} 1 \mathrm{~b}}=0.095(p<0.01)$

Cramers $\mathrm{V}_{\mathrm{S} 1 \mathrm{a} \times \mathrm{S} 2}=0.174(p<0.001)$

Cramers $\mathrm{V}_{\mathrm{S} 1 \mathrm{~b} \times \mathrm{S} 2}=0.125(p<0.05)$

Cramers $\mathrm{V}_{\mathrm{S} 1 \mathrm{a} \times \mathrm{S} 1 \mathrm{~b} \& \mathrm{~S} 2=0.173(p<0.001)}$

\begin{tabular}{llll}
\hline & $\mathrm{S}_{1 \mathrm{a}}$ & $\mathrm{S}_{1 \mathrm{~b}}$ & $\mathrm{~S}_{2}$ \\
\hline Male & 47 & 51 & 62 \\
Female & 53 & 49 & 38 \\
$(N=)$ & 100 & 100 & 100 \\
& $(1797)$ & $(197)$ & $(367)$ \\
\hline
\end{tabular}

Cramers $\mathrm{V}_{\text {total }}=0.109(p<0.001)$

Cramers V $1 \mathrm{a} \times \mathrm{S} 1 \mathrm{~b}=0.021$ (n.s.)

Cramers $\mathrm{V}_{\mathrm{S} 1 \mathrm{a} \times \mathrm{S} 2}=0.114(p<0.001)$

Cramers $\mathrm{V}_{\mathrm{S} 1 \mathrm{~b} \times \mathrm{S} 2}=0.113(p<0.05)$

Cramers $\mathrm{V}_{\mathrm{S} 1 \mathrm{a} \times \mathrm{S} 1 \mathrm{~b} \& \mathrm{~S} 2=0.095(p<0.001)}$

\begin{tabular}{llll}
\hline & $\mathrm{S}_{1 \mathrm{a}}$ & $\mathrm{S}_{1 \mathrm{~b}}$ & $\mathrm{~S}_{2}$ \\
\hline Less than Abitur & 47 & 33 & 18 \\
Abitur and higher & 54 & 68 & 82 \\
$(N=)$ & 100 & 100 & 100 \\
& $(1819)$ & $(200)$ & $(394)$ \\
\hline
\end{tabular}

Cramers $\mathrm{V}_{\text {total }}=0.220(p<0.001)$

Cramers $\mathrm{V}_{\mathrm{S} 1 \mathrm{a} \times \mathrm{S} 1 \mathrm{~b}}=0.084(p<0.001)$

Cramers $\mathrm{V}_{\mathrm{S} 1 \mathrm{a} \times \mathrm{S} 2}=0.223(p<0.001)$

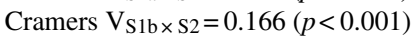

Cramers VS1a $\times$ S1b \& S2 $=0.208(p<0.001)$ 


\section{Reasons for not participating in online consultation}

Note: Figures in italics represent those variables that primarily load on this factor. Though normally the items that are deployed as the basis for such an analysis should be at least interval-scaled with at least four values (Kim and Mueller 1978, p. 74), it is possible to use dichotomous variables as long as the assumption of an underlying linear-additive structure is reasonable, which in the end results in a factorization of the respective $\Phi$-coefficients (Arminger 1979, p. 159).

The questions for this item were worded as follows:

\begin{tabular}{|c|c|}
\hline German original & English translation \\
\hline $\begin{array}{l}\text { Können Sie sich noch erinnern, warum Sie nicht } \\
\text { teilgenommen haben? } \\
\text { (Mehrfachnennungen möglich) }\end{array}$ & $\begin{array}{l}\text { Can you still remember why you did not par- } \\
\text { ticipate? } \\
\text { (Multiple responses allowed) }\end{array}$ \\
\hline Zweifel daran, mit der Beteiligung etwas zu erreichen & $\begin{array}{l}\text { Doubts about achieving anything through } \\
\text { participation }\end{array}$ \\
\hline Das Ziel des Beteiligungsverfahrens war mir unklar & $\begin{array}{l}\text { The goal of the participation process was not } \\
\text { clear to me }\end{array}$ \\
\hline Technische Probleme mit der Online-Plattform & Technical problems with online platform \\
\hline Sorge um die Sicherheit meiner Daten & Concern about the security of my data \\
\hline Ich halte grundsätzlich nichts von Online-Beteiligung & I do not like online participation in general \\
\hline $\begin{array}{l}\text { Ich war zufrieden mit dem Diskussionsverlauf und } \\
\text { habe keinen Anlass gesehen, selbst aktiv zu werden }\end{array}$ & $\begin{array}{l}\text { I was satisfied with the discussion and did not } \\
\text { see a need to become active myself }\end{array}$ \\
\hline Kein Interesse am Thema & No interest in topic \\
\hline Ich sehe keinen Verbesserungsbedarf im Radverkehr & $\begin{array}{l}\text { I do not see any need for improvement in } \\
\text { relation to cycling }\end{array}$ \\
\hline $\begin{array}{l}\text { Ich habe bereits auf anderem Wege } \\
\text { Verbesserungsvorschläge gemacht }\end{array}$ & $\begin{array}{l}\text { I already submitted proposals for improve- } \\
\text { ment via other means }\end{array}$ \\
\hline
\end{tabular}


Table 12 Dimensions of reasons for absence from consultation. (Source: Survey of citizens of Bonn,

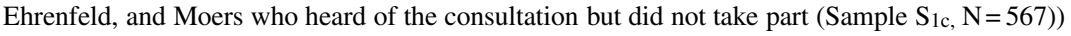

\begin{tabular}{lllll}
\hline & $\begin{array}{l}\text { Public participa- } \\
\text { tion distrust }\end{array}$ & $\begin{array}{l}\text { Online- } \\
\text { aversion }\end{array}$ & $\begin{array}{l}\text { Agreeing } \\
\text { passivity }\end{array}$ & $\begin{array}{l}\text { No problem left } \\
\text { to be solved }\end{array}$ \\
\hline $\begin{array}{l}\text { Effectiveness doubts } \\
\begin{array}{l}\text { Unclear goals of partici- } \\
\text { pation process }\end{array}\end{array}$ & 0.774 & -0.060 & -0.106 & 0.031 \\
$\begin{array}{l}\text { Technical problems } \\
\begin{array}{l}\text { Concerns with data secu- } \\
\text { rity }\end{array}\end{array}$ & -0.215 & 0.066 & 0.034 & 0.030 \\
$\begin{array}{l}\text { Categorically against } \\
\text { online participation }\end{array}$ & 0.125 & 0.704 & 0.001 & -0.124 \\
$\begin{array}{l}\text { Already satisfied with } \\
\text { discussion }\end{array}$ & -0.202 & 0.641 & -0.002 & 0.287 \\
$\begin{array}{l}\text { Not interested } \\
\text { No need for improvement }\end{array}$ & 0.045 & 0.538 & -0.023 & -0.022 \\
$\begin{array}{l}\text { Deployed other channels } \\
\text { \% of explained variance }\end{array}$ & -0.003 & -0.148 & 0.865 & 0.151 \\
\hline
\end{tabular}

Method: orthogonal principal component analysis, factor loadings (varimax rotated, extraction method: Kaiser criterion) 


\section{Evaluation of dimensions of the consultation process}

Table 13 Evaluation of consultation by participants. (Source: Survey of participants of online consultation in Bonn, Ehrenfeld, and Moers $\left(\mathrm{S}_{1 \mathrm{~b}} \& \mathrm{~S}_{2}\right)$ )

\begin{tabular}{|c|c|c|c|c|}
\hline & $\begin{array}{l}\text { Disagree } \\
\text { (com- } \\
\text { pletely) }\end{array}$ & $\begin{array}{l}\text { Half } \\
\text { and half }\end{array}$ & $\begin{array}{l}\text { Agree } \\
\text { (com- } \\
\text { pletely) }\end{array}$ & $\begin{array}{l}\text { Don't } \\
\text { know }\end{array}$ \\
\hline \multicolumn{5}{|l|}{ Throughput-Factors } \\
\hline $\begin{array}{l}\text { "The information provided on the online platform } \\
\text { about the operating principles of the online platform } \\
\text { was sufficient." } \\
\text { (Usability 1) }\end{array}$ & 8 & 12 & 69 & 11 \\
\hline $\begin{array}{l}\text { "Overall I was satisfied with the usability of the } \\
\text { online platform." (Usability 2) }\end{array}$ & 9 & 20 & 64 & 8 \\
\hline $\begin{array}{l}\text { "On the online platform all relevant information was } \\
\text { easy to find." } \\
\text { (Transparency of Process) }\end{array}$ & 10 & 20 & 59 & 12 \\
\hline $\begin{array}{l}\text { "The information provided on the online platform } \\
\text { about the goals of the participation process was } \\
\text { sufficient." } \\
\text { (Transparency of Goals) }\end{array}$ & 9 & 22 & 57 & 13 \\
\hline $\begin{array}{l}\text { "By the time the process took place it was uncer- } \\
\text { tain what will happen to the citizens' proposals for } \\
\text { improvement." } \\
\text { (Transparency of Outcome) }\end{array}$ & 7 & 14 & 68 & 11 \\
\hline $\begin{array}{l}\text { "The moderation on the online platform was fair." } \\
\text { (Fairness 1) }\end{array}$ & 3 & 9 & 54 & 34 \\
\hline $\begin{array}{l}\text { "The interventions by the moderation (e.g. reas- } \\
\text { signing proposals in another topic category) were } \\
\text { justified." } \\
\text { (Fairness 2) }\end{array}$ & 2 & 13 & 42 & 43 \\
\hline $\begin{array}{l}\text { "I would also have participated in the process if } \\
\text { it had not taken place online but in the context of } \\
\text { events on location." } \\
\text { (Participation Mode 1) }\end{array}$ & 41 & 16 & 33 & 11 \\
\hline $\begin{array}{l}\text { "It was appropriate to let the participation process } \\
\text { take place exclusively online." } \\
\text { (Participation Mode 2) }\end{array}$ & 15 & 15 & 63 & 7 \\
\hline \multicolumn{5}{|l|}{ Output-Factors } \\
\hline $\begin{array}{l}\text { "Due to the participants' contributions on the online } \\
\text { platform, a realistic picture of the state of cycle } \\
\text { traffic in [city] emerged." } \\
\text { (Output-Quality 1) }\end{array}$ & 7 & 25 & 58 & 10 \\
\hline $\begin{array}{l}\text { "Overall, the contributions and proposals of the } \\
\text { users were of high quality." } \\
\text { (Output-Quality 2) }\end{array}$ & 4 & 25 & 60 & 12 \\
\hline $\begin{array}{l}\text { "By and large the contributions on the platform } \\
\text { were constructive and relevant to the question of } \\
\text { how the cycle traffic situation in [city] could be } \\
\text { improved." } \\
\text { (Output-Quality 3) }\end{array}$ & 2 & 14 & 74 & 9 \\
\hline
\end{tabular}


Table 13 (Continued)

\begin{tabular}{|c|c|c|c|c|}
\hline & $\begin{array}{l}\text { Disagree } \\
\text { (com- } \\
\text { pletely) }\end{array}$ & $\begin{array}{l}\text { Half } \\
\text { and half }\end{array}$ & $\begin{array}{l}\text { Agree } \\
\text { (com- } \\
\text { pletely) }\end{array}$ & $\begin{array}{l}\text { Don't } \\
\text { know }\end{array}$ \\
\hline $\begin{array}{l}\text { "I assume that the contributions of the [name of } \\
\text { consultation process] will play an important role in } \\
\text { the future planning of cycle traffic." } \\
\text { (Outcome-Expectation) }\end{array}$ & 31 & 23 & 39 & 7 \\
\hline $\begin{array}{l}\text { "I think that the [name of consultation process] } \\
\text { in [city] will improve the cycle traffic situation in } \\
\text { [city]." } \\
\text { (Impact Expectation) }\end{array}$ & 33 & 24 & 38 & 6 \\
\hline
\end{tabular}

Table 14 Dimensions of participants' evaluations of process and results. (Source: Survey of participants of online consultation in Bonn, Ehrenfeld, and Moers $\left(\mathrm{S}_{1 \mathrm{~b}} \& \mathrm{~S}_{2}\right)$ )

\begin{tabular}{|c|c|c|c|c|c|}
\hline & $\begin{array}{l}\text { Usability/ } \\
\text { Transparency }\end{array}$ & $\begin{array}{l}\text { Output } \\
\text { Quality }\end{array}$ & $\begin{array}{l}\text { Outcome/Impact- } \\
\text { Expectation }\end{array}$ & Fairness & $\begin{array}{l}\text { Mode of Par- } \\
\text { ticipation }\end{array}$ \\
\hline Usability 2 & 0.868 & 0.108 & 0.076 & 0.052 & 0.034 \\
\hline $\begin{array}{l}\text { Transparency of } \\
\text { Process }\end{array}$ & 0.850 & 0.156 & 0.102 & 0.121 & 0.076 \\
\hline Usability 1 & 0.740 & 0.147 & 0.022 & 0.277 & 0.193 \\
\hline $\begin{array}{l}\text { Transparency of } \\
\text { Goals }\end{array}$ & 0.685 & 0.160 & 0.163 & 0.134 & 0.032 \\
\hline $\begin{array}{l}\text { Output-Qual- } \\
\text { ity } 2\end{array}$ & 0.115 & 0.850 & -0.029 & -0.025 & 0.009 \\
\hline $\begin{array}{l}\text { Output-Qual- } \\
\text { ity } 3\end{array}$ & 0.164 & 0.839 & 0.056 & 0.130 & -0.004 \\
\hline $\begin{array}{l}\text { Output-Qual- } \\
\text { ity } 1\end{array}$ & 0.187 & 0.628 & 0.175 & 0.184 & 0.098 \\
\hline $\begin{array}{l}\text { Impact-Expec- } \\
\text { tation }\end{array}$ & 0.099 & 0.082 & 0.920 & 0.019 & 0.012 \\
\hline $\begin{array}{l}\text { Outcome-Ex- } \\
\text { pectation }\end{array}$ & 0.161 & 0.065 & 0.919 & 0.007 & -0.018 \\
\hline Fairness 2 & 0.141 & 0.098 & -0.048 & 0.876 & 0.038 \\
\hline Fairness 1 & 0.245 & 0.124 & 0.082 & 0.832 & -0.010 \\
\hline $\begin{array}{l}\text { Participation } \\
\text { Mode }\end{array}$ & -0.007 & 0.091 & 0.015 & 0.099 & -0.882 \\
\hline $\begin{array}{l}\text { Participation } \\
\text { Mode } 2\end{array}$ & 0.277 & 0.241 & 0.014 & 0.188 & 0.655 \\
\hline $\begin{array}{l}\% \text { of explained } \\
\text { variance }\end{array}$ & 21.237 & 15.437 & 13.674 & 12.837 & 9.725 \\
\hline
\end{tabular}

Dimensions based on orthogonal principal component analysis (varimax rotated, extraction method: Kaiser criterion)

Figures in italics represent those variables that primarily load on this factor 


\section{Diffusion of knowledge about consultation}

Table 15 Determinants of information diffusion concerning consultation inside control group (logistic regression). (Source: Sample S1, field experimentcontrol group $(\mathrm{N}=542)$, i.e. only those respondents who did not receive an invitation letter)

\begin{tabular}{|c|c|c|c|c|}
\hline & \multicolumn{2}{|l|}{ Model I } & \multicolumn{2}{|l|}{ Model II } \\
\hline & Wald & $\operatorname{Exp}(b)$ & Wald & $\operatorname{Exp}(b)$ \\
\hline$\overline{\text { Constant }}$ & $15.356^{* * *}$ & & 2.945 & \\
\hline \multicolumn{5}{|l|}{ Agegroups } \\
\hline (Reference: 18-29) & $17.317^{* *}$ & & $13.091^{* *}$ & \\
\hline $30-44$ & 0.051 & 1.103 & 0.208 & 1.224 \\
\hline $45-59$ & 1.067 & 1.537 & 1.269 & 1.614 \\
\hline $60+$ & $7.853^{* *}$ & 3.103 & $7.108^{* *}$ & 3.019 \\
\hline \multicolumn{5}{|l|}{ Gender } \\
\hline Female & 0.059 & 0.950 & 0.081 & 0.940 \\
\hline \multicolumn{5}{|l|}{ Education } \\
\hline Abitur or higher & 0.069 & 0.941 & 0.771 & 0.800 \\
\hline \multicolumn{5}{|c|}{ Internal Political Efficacy } \\
\hline (Reference: 0-5) & 3.023 & & 2.288 & \\
\hline $6.25-7.5$ & 0.525 & 0.830 & 0.510 & 0.821 \\
\hline $8.75-10$ & 0.879 & 1.298 & 0.457 & 1.225 \\
\hline \multicolumn{5}{|l|}{ Political Action Scale } \\
\hline (Reference: $0-1$ ) & & & 5.846 & \\
\hline $2-4$ & & & 0.069 & 0.922 \\
\hline $5-7$ & & & 1.219 & 0.678 \\
\hline $8+$ & & & 1.169 & 1.473 \\
\hline \multicolumn{5}{|l|}{ Daily biking distance } \\
\hline (Reference: $0 \mathrm{~km}$ ) & & & 1.990 & \\
\hline $0.25-4.5 \mathrm{~km}$ & & & 1.410 & 0.716 \\
\hline $5-9.5 \mathrm{~km}$ & & & 0.325 & 0.832 \\
\hline $10+\mathrm{km}$ & & & 0.031 & 1.055 \\
\hline \multicolumn{5}{|l|}{ City } \\
\hline (Reference: Bonn) & & & $11.497^{* *}$ & \\
\hline Ehrenfeld & & & $10.792^{* *}$ & 0.400 \\
\hline Moers & & & $5.791^{*}$ & 0.518 \\
\hline $\begin{array}{l}\text { Pseudo- } R^{2} \text { (Nagelk- } \\
\text { erke) }\end{array}$ & 0.069 & & 0.118 & \\
\hline
\end{tabular}

$* p<0.05 ; * * p<0.01 ; * * * p<0.001$

Variable Operationalization: dependent variable: heard of the consultation or participated $=1$, neither heard of nor participated $=0$; independent variables: see Table 2 


\section{References}

Åström, J., and Å. Grönlund. 2011. Online consultations in local government: what works, when, and why? In Connecting democracy, ed. S. Coleman, P.M. Shane https://doi.org/10.7551/mitpress/9006. 003.0006.

Aichholzer, G., H. Kubicek, and L. Torres. 2016. Evaluating e-participation. Frameworks, practice, evidence. https://doi.org/10.1007/978-3-319-25403-6.

Anduiza, E., M.J. Jensen, and L. Jorba. 2012. Digital media and political engagement worldwide. A comparative study. Cambridge: Cambridge University Press.

Arminger, G. 1979. Statistik für Soziologen: Faktorenanalyse. Stuttgart: Teubner.

Barber, B.R. 1984. Strong democracy: participatory politics for a new age. Berkeley: University of California Press.

Bartels, L.M. 2008. Unequal democracy—the political economy of the new gilded age. Princeton: Princeton University Press.

Beierlein, C., A. Kovaleva, C.J. Kemper, and B. Rammstedt. 2012. Ein Messinstrument zur Erfassung subjektiver Kompetenzerwartungen. GESIS-working papers, Vol. 17 http://nbn-resolving.de/urn:nbn: de:0168-ssoar-292351.

Boulianne, S. 2009. Does Internet use affect engagement? A meta-analysis of research. Political Соттиnication 26(2):193-211. https://doi.org/10.1080/10584600902854363.

Boulianne, S. 2011. Stimulating or reinforcing political interest: using panel data to examine reciprocal effects between news media and political interest. Political Communication 28(2):147-162. https:// doi.org/10.1080/10584609.2010.540305.

Colombo, C., C. Galais, and A. Gallego. 2012. Internet use and political attitudes in Europe. In Digital media and political engagement worldwide, ed. E. Anduiza, M.J. Jensen, and L. Jorba, 102-117. Cambridge: Cambridge University Press.

Dahl, R.A. 1989. Democracy and its critics. Yale: Yale University Press.

Dalton, R.J. 2004. Democratic challenges, democratic choices: the erosion of political support in advanced industrial democracies. https://doi.org/10.1093/acprof:oso/9780199268436.001.0001.

Dalton, R.J. 2017. The participation gap. Social status and political inequality. Oxford: Oxford University Press.

van Deth, J.W., and M. Tausendpfund (eds.). 2013. Politik im Kontext: Ist alle Politik lokale Politik? https:// doi.org/10.1007/978-3-531-19249-9.

Diefenbach, I. 2013. Mehr Bürgerbeteiligung? Eine empirische Studie zur Onlineplattform Liquid Friesland. Emden: Hochschule Emden/Leer.

Diekmann, A. 2004. Empirische Sozialforschung: Grundlagen, Methoden, Anwendungen. Reinbek bei Hamburg: Rowohlt.

Dillman, D.A., V. Lesser, R. Mason, J. Carlson, F. Willits, R. Robertson, and B. Burke. 2007. Personalization of mail surveys for general public and populations with a group identity: results from nine studies. Rural Sociology 72(4):632-646. https://doi.org/10.1526/003601107782638693.

Einstein, K.L., M. Palmer, and D.M. Glick. 2019. Who participates in local government? Evidence from meeting minutes. Perspectives on Politics 17(1):28-46. https://doi.org/10.1017/S153759271800213X.

Elsässer, L., S. Hense, and A. Schäfer. 2017. „Dem Deutschen Volke“? Die ungleiche Responsivität des Bundestags. Zeitschrift Für Politikwissenschaft 27(2):161-180. https://doi.org/10.1007/s41358-0170097-9.

Emmer, M., G. Vowe, and J. Wolling. 2011. Bürger online: Die Entwicklung der politischen Online-Kommunikation in Deutschland, 1st edn., Konstanz: UVK.

Escher, T. 2013. Mobilisierung zu politischer Partizipation durch das Internet: Erwartungen, Erkenntnisse und Herausforderungen der Forschung. Analyse \& Kritik 35(2):449-476.

Escher, T., and U. Riehm. 2017. Petitioning the German Bundestag: political equality and the role of the Internet. Parliamentary Affairs 70(1):132-154. https://doi.org/10.1093/pa/gsw009.

Faas, T., A. Paust, and A. Renkamp. 2016. Das Beteiligungsverfahren zum Transparenzgesetz RheinlandPfalz. Evaluation des partizipativen Gesetzgebungsverfahrens. Gütersloh: Bertelsmann Stiftung.

Ferrín, M., and H. Kriesi (eds.). 2016. How Europeans view and evaluate democracy. https://doi.org/10. 1093/acprof:oso/9780198766902.001.0001.

Freschi, A., R. Medaglia, and J. Nørbjerg. 2009. A tale of six countries: eparticipation research from an administration and political perspective. In Electronic participation, Vol. 5694, ed. A. Macintosh, E. Tambouris, 36-45. https://doi.org/10.1007/978-3-642-03781-8_4. 
Fung, A. 2006. Varieties of Participation in Complex Governance. Public Administration Review https:// doi.org/10.1111/j.1540-6210.2006.00667.x/full.

Gabriel, O.W. 2013. Politische Partizipation. In Politik im Kontext: Ist alle Politik lokale Politik?, ed. J.W. van Deth, M. Tausendpfund, 381-411. https://doi.org/10.1007/978-3-531-19249-9_14.

Gabriel, O.W., and N. Kersting. 2014. Politisches Engagement in deutschen Kommunen: Strukturen und Wirkungen auf die politischen Einstellungen von Bürgerschaft, Politik und Verwaltung. In Partizipation im Wandel, ed. Bertelsmann Stiftung, Staatsministerium Baden-Württemberg, 43-181. Gütersloh: Bertelsmann Stiftung.

Gabriel, O.W., and K. Völkl. 2008. Politische und soziale Partizipation. In Die EU-Staaten im Vergleich, ed. O.W. Gabriel, S. Kropp, 268-298. https://doi.org/10.1007/978-3-531-91075-8_10.

Gibson, R., W. Lusoli, and S. Ward. 2005. Online participation in the UK: testing a 'contextualised' model of Internet effects. The British Journal of Politics and International Relations 7:561-583. https://doi. org/10.1111/j.1467-856x.2005.00209.x.

Gilens, M. 2005. Inequality and democratic responsiveness. Public Opinion Quarterly 69(5):778-796. https://doi.org/10.1093/poq/nfi058.

Habermas, J. 1992. Faktizität und Geltung: Beiträge zur Diskurstheorie des Rechts und des demokratischen Rechtsstaats. 2n edition. Frankfurt am Main: Suhrkamp.

van Ham, C., J. Thomassen, K. Aarts, and R. Andeweg (eds.). 2017. Myth and reality of the legitimacy crisis. Vol. 1 https://doi.org/10.1093/oso/9780198793717.001.0001.

Helsper, E.J., and B.C. Reisdorf. 2017. The emergence of a "digital underclass" in Great Britain and Sweden: changing reasons for digital exclusion. New Media \& Society 19(8):1253-1270. https://doi. org/10.1177/1461444816634676.

Hoffmeyer-Zlotnik, J.H.P., and U. Warner. 1998. Die Messung von Einkommen im nationalen und internationalen Vergleich. ZUMA Nachrichten 42(22):30-70.

Jorba, L., and B. Bimber. 2012. The impact of digital media on citizenship from a global perspective. In Digital media and political engagement worldwide, ed. E. Anduiza, M.J. Jensen, and L. Jorba, 16-55. Cambridge: Cambridge University Press.

Karpf, D. 2010. Online political mobilization from the advocacy group's perspective: looking beyond clicktivism. Policy \& Internet 2(4):7-41. https://doi.org/10.2202/1944-2866.1098/abstract.

Kim, J., and C.W. Mueller. 1978. Factor analysis: Statistical methods and practical issues. Newbury Park, CA: SAGE.

Kim, S., and J. Lee. 2012. E-participation, transparency, and trust in local government. Public Administration Review 72(6):879-828. https://doi.org/10.1111/j.1540-6210.2012.02593.x.

Kneip, S., W. Merkel, and B. Weßels (eds.). 2020. Legitimitätsprobleme. https://doi.org/10.1007/978-3658-29558-5.

Kroh, M., and H. Neiss. 2012. On the causal nature of the relationshiop between Internet access and political engagement: evidence from Germany. In Digital media and political engagement worldwide, ed. E. Anduiza, M.J. Jensen, and L. Jorba, 160-176. Cambridge: Cambridge University Press.

Kubicek, H., and G. Aichholzer. 2016. Closing the evaluation gap in e-participation research and practice. In Evaluating e-participation, 11-45. https://doi.org/10.1007/978-3-319-25403-6_2.

Kubicek, H., and H. Westholm. 2010. Consensus building by blended participation in a local planning process: the case of the public stadium swimming pool in Bremen. In e-Democracy. A group decision and negotiation perspective, ed. D. Rios Insua, S. French, 323-341. https://doi.org/10.1007/978-90481-9045-4.

Kubicek, H., B. Lippa, and A. Koop. 2011. Erfolgreich beteiligt? Nutzen und Erfolgsfaktoren internetgestuetzter Buergerbeteiligung - Eine empirische Analyse von 12 Fallbeispielen. Guetersloh: Bertelsmann Stiftung.

Kubicek, H., B. Lippa, and H. Westholm. 2009. Medienmix in der Bürgerbeteiligung: die Integration von Online-Elementen in Beteiligungsverfahren auf lokaler Ebene. Berlin: Sigma.

Lijphart, A. 1997. Unequal participation: democracy's unresolved dilemma. The American Political Science Review 91(1):1-14. https://doi.org/10.2307/2952255.

Lupia, A., and G. Sin. 2003. Which public goods are endangered? How evolving communication technologies affect the logic of collective action. Public Choice 117(3/4):315-331. https://doi.org/10.1023/B: PUCH.0000003735.07840.c7.

Märker, O., and M. Ruesch. 2012. Statistische Auswertung der Bürgerbeteiligung an der Lärmaktionsplanung in Dortmund. Dortmund: Umweltamt Stadt Dortmund.

Marr, M., and N. Zillien. 2010. Digitale Spaltung. In Handbuch Online-Kommunikation, ed. W. Schweiger, K. Beck, 257-282. https://doi.org/10.1007/978-3-531-92437-3. 
Marschall, S., and M. Schultze. 2012. Voting advice applications and their effect on voter turnout: the case of the German Wahl-O-mat. International Journal of Electronic Governance https://doi.org/10.1504/ IJEG.2012.051314.

Maxhofer, P. 2019. Das Beteiligungsportal des Landes Baden-Württemberg. In Gesetzgebung mit Bürgerbeteiligung, 79-151. https://doi.org/10.1007/978-3-658-24144-5_2.

Michels, A., and L. de Graaf. 2010. Examining citizen participation: local participatory policy making and democracy. Local Government Studies 36(4):477-491. https://doi.org/10.1080/03003930.2010. 494101.

Norris, P. 2000. A virtuous circle: political communications in postindustrial societies, and politics. Cambridge: Cambridge University Press.

Norris, P. 2001. Digital divide: civic engagement, information poverty, and the Internet worldwide. Cambridge: Cambridge University Press.

Norris, P. 2011. Democratic Deficit: Critical Citizens Revisited. Cambridge, GBR: Cambridge University Press.

Oser, J., M. Hooghe, and S. Marien. 2012. Is Online participation distinct from offline participation? A latent class analysis of participation types and their stratification. Political Research Quarterly 66(1):91-101. https://doi.org/10.1177/1065912912436695.

Pateman, C. 1970. Participation and democratic theory. Cambridge: Cambridge University Press.

Pitkin, H.F. 1967. The Concept of Representation. Berkeley: University of California Press.

Prior, M. 2005. News vs. entertainment: how increasing media choice widens gaps in political knowledge and turnout. American Journal of Political Science 49(3):577-592. https://doi.org/10.1111/j.15405907.2005.00143.x.

Ritzi, C., and A. Wagner. 2016. Symbolisch oder echt? Die politische Beteiligung junger Erwachsener in Deutschland online und offline. Zeitschrift Für Parlamentsfragen 47(2):304-326. https://doi.org/10. 5771/0340-1758-2016-2-304.

Schäfer, A. 2012. Consequences of social inequality for democracy in Western Europe. Zeitschrift Für Vergleichende Politikwissenschaft 6(S2):23-45. https://doi.org/10.1007/s12286-010-0086-6.

Schlozman, K.L., S. Verba, and H.E. Brady. 2010. Weapon of the strong? Participatory inequality and the Internet. Perspectives on Politics 8(02):487-509. https://doi.org/10.1017/S1537592710001210.

Schneider, S.H. 2018. Bürgerhaushalte in Deutschland. Individuelle und kontextuelle Einflussfaktoren der Beteiligung. https://doi.org/10.1007/978-3-658-19030-9.

Schöttle, S. 2019. Politische Online-Partizipation und soziale Ungleichheit. https://doi.org/10.1007/9783-658-28154-0.

Sinclair, M., J. O’Toole, M. Malawaraarachchi, and K. Leder. 2012. Comparison of response rates and cost-effectiveness for a community-based survey: postal, internet and telephone modes with generic or personalised recruitment approaches. BMC Medical Research Methodology 12(1):132. https://doi. org/10.1186/1471-2288-12-132.

Smith, G. 2009. Democratic innovations: designing institutions for citizen participation (theories of institutional design). Cambridge: Cambridge University Press.

Stark, T. 2019. Demokratische Bürgerbeteiligung außerhalb des Wahllokals. https://doi.org/10.1007/9783-658-24616-7.

Steinbach, M., N. Wilker, and S. Schöttle. 2020. E-participation on the local level-a census survey approach for researching its implementation. Journal of Information Technology \& Politics 17(1):12-32. https://doi.org/10.1080/19331681.2019.1676361.

Steinbrecher, M. 2009. Politische Partizipation in Deutschland, 1st edn., Baden-Baden: Nomos.

Susha, I., and Å. Grönlund. 2012. eParticipation research: systematizing the field. Government Information Quarterly 29(3):373-382. https://doi.org/10.1016/j.giq.2011.11.005.

Taubert, N., W. Krohn, and T. Knobloch. 2010. Evaluierung des Kölner Bürgerhaushalts. Endbericht. Bielefeld: Stadt Köln.

Theocharis, Y., and J.W. van Deth. 2018. Political participation in a changing world. Oxford: Routledge.

Verba, S. 2003. Would the dream of political equality turn out to be a nightmare? Perspectives on Politics 1(4):663-679. https://doi.org/10.1017/S1537592703000458.

Verba, S., K.L. Schlozman, and H.E. Brady. 1995. Voice and equality: civic voluntarism in American politics. Cambridge, MA: Harvard University Press.

Vetter, A. (ed.). 2008. Erfolgsbedingungen lokaler Bürgerbeteiligung. https://doi.org/10.1007/978-3-53109026-9.

Wampler, B., and R.C. Sampaio. 2011. Belo Horizonte, Brazil: Co-Governance. Gütersloh: Bertelsmann Stiftung. 